\title{
A variable morfolóxica animais / animaes / animás / animales / animals no galego contemporáneo ${ }^{1}$
}

\author{
Ramón Mariño Paz \\ Universidade de Santiago de Compostela
}

\begin{abstract}
Resumo:
Neste traballo analízase como o purismo e a estandarización influíron no moderno desenvolvemento dunha variable morfolóxica da lingua galega: o plural dos nomes polisílabos agudos terminados en $/-1 /$ no singular.
\end{abstract}

Palabras chave:

Purismo lingüístico, estandarización, lingua galega.

\begin{abstract}
:
In this paper I study how purism and standardization influenced in the modern development of a morphological variable of the Galician language: the plural of the polysyllabical acute nouns finished in $/-l /$ in their singular form.
\end{abstract}

Key words:

Critical Linguistic purism, standardization, Galician language.

\section{Obxecto de estudo e metodoloxía}

No galego medieval estes plurais adoitaban formarse coa supresión da consoante lateral final e a adición do alomorfo -es (leal - leaes, cabedel - cabedees, catasol - catasoes, azul - azues) ou do alomorfo -is (gentil - gentijs). Pola súa parte, a innovación morfolóxica consistente en manter no plural a consoante final do singular e engadir o alomorfo -es (catedral - catedrales, sotil - sotiles) presentábase en xeral en porcentaxes residuais, con excepcións como as da Crónica de Castela

1 Este artigo é unha versión bastante ampliada destoutro que hai uns anos publiquei na revista Linguística da Universidade do Porto: R. Mariño Paz (2008): "O purismo e a estandarización como factores condicionantes da mudanza lingüística. $\mathrm{O}$ caso dos plurais dos nomes polisílabos agudos terminados en /-1/ no singular no galego contemporáneo", Linguística. Revista de Estudos Linguísticos da Universidade do Porto, III, 1, 155-176. 
e da Crónica Particular de San Fernando da Crónica Xeral Galega (1295-1312) e do Libro de notas de Álvaro Pérez (1457). As ocorrencias en que esta innovación se manifestou, cando non se deberon simplemente a traducións servís dos textos ou das fórmulas notariais castelás que se estaban a verter para o galego, talvez se poidan explicar como resultado da atracción analóxica exercida tanto polo modelo das palabras que formaban o plural engadindo o morfema -es pero sen eliminaren a consoante final do lexema (amor - amores, mes - meses, voz - vozes) coma polo daqueles polisílabos non oxítonos e monosílabos terminados en /-1/ no singular que nunca ou raramente coñeceron outra solución para os seus plurais (perdurauilles, viles, vales, etc.).

Durante os séculos XVI, XVII e XVIII produciuse en galego unha certa progresión dos plurais en terminados -les para o tipo de nomes polisílabos agudos que se estudan neste traballo. Ora ben, é probable que na lingua galega oral das camadas populares este avance fose menor ca o que se observa nas escasas fontes escritas da época que se conservan, fontes que, obviamente, foron producidas por representantes das exiguas minorías que daquela sabían escribir e que case sempre o facían en castelán. Outra conclusión que semella irrebatible é a de que naquel tempo gozaron de grande extensión as solucións que resolveron mediante asimilación e coalescencia (ou só coalescencia) os antigos hiatos $<$ aes $>$, $<$ ees $>$ e $<$ oes $>$ : reaes $>$ reaas $>$ reás, pichees $>$ pichés, españoes $>$ españoos $>$ españós ${ }^{2}$.

$\mathrm{O}$ incremento do número de individuos bilingües con coñecemento activo do galego e do castelán que se produciu sobre todo no século XX propiciou o avance da variante desta variable morfolóxica que supoñía unha converxencia co único idioma oficial en España durante a maior parte da Idade Contemporánea (animales, españoles...), nomeadamente nos contextos vilegos e urbanos ${ }^{3}$. Ao mesmo tempo, o

2 Para máis detalles sobre a evolución desta variable morfolóxica desde a Idade Media ata o século XIX, cf. Mariño Paz (2004).

3 Neste artigo non me propoño abrir unha discusión sobre se esta innovación se debe interpretar ou non como un préstamo estrutural que o galego tomou do castelán. Limitareime por tanto a afirmar que, se é certo que o préstamo de morfemas flexionais esixe entre as linguas doadora e receptora un contacto máis intenso ca o que pide o préstamo de morfemas derivativos ou de elementos fónicos ou lexicais (cf. McMahon 1994: 209-213), o contacto galego-castelán ten xa en Galicia antigüidade e intensidade abondas para producir transferencias de morfemas flexionais. Máis aínda, no último século produciuse un rápido aumento do número de individuos con competencia activa en ambas as linguas que creou condicións idóneas para que no galego xurdan e se espallen préstamos estruturais de distinto tipo tomados do castelán ou para que avancen con máis rapidez aquelas variantes lingüísticas que, aínda que fosen xeradas autonomamente polo galego, camiñan na dirección da converxencia co castelán. En todo caso, o que me interesa subliñar no inicio deste traballo é que ao longo dos séculos XIX e XX diversos observadores tiveron a percepción de que a variante animales se utiliza en galego por castelanismo e, en consecuencia, que non foron poucos os gramáticos e escritores que, como resposta a tal percepción, utilizaron ou chamaron a utilizar variantes de plural sobre as que non pesase tal inconveniente. 
cultivo rexenerador do galego sustentado polo galeguismo desde mediados do XIX supuxo a posta en práctica de actitudes puristas que intentaron descastelanizalo de diversas maneiras. Aprobada a Constitución española de 1978, Galicia converteuse nunha Comunidade Autónoma con rango de histórica e o seu Estatuto de Autonomía de 1981 declarou o galego lingua cooficial no seu territorio, o que inmediatamente supuxo que se lle reservasen distintos usos de carácter formal: nas administracións públicas, no ensino, na vida política, nos medios de comunicación públicos e nalgúns privados, etc. En 1982 publicáronse as Normas ortográficas e morfolóxicas do idioma galego da Real Academia Galega (RAG) e o Instituto da Lingua Galega (ILG), axiña declaradas oficiais. O primeiro dos catro principios que se presentaron como inspiradores destas Normas non era outra cousa ca unha transparente declaración de purismo descastelanizador:

\begin{abstract}
A lingua normativa ten que estar ó servicio da cultura dun pobo real e concreto, e por tanto ha de ser necesariamente continuadora da lingua falada pola comunidade e ha de achegarse canto sexa posible a ela, a fin de enraizar sobre bases seguras e vivas. Agora ben, para que estas bases sexan efectivamente sólidas, a normativa debe acoller un galego fiel a si mesmo e limpo de canto de espúreo hai incrustado na fala viva pola presión do castelán. É dicir, a lingua común debe se-lo máis galega posible, establecida sen sometementos nin dependencias, con atención escrupulosa á estructura e características lingüísticas do galego (Real Academia Galega / Instituto da Lingua Galega 1982: 7) ${ }^{4}$.
\end{abstract}

Para a variable morfolóxica estudada neste artigo, a selección da variante animais, hoxe minoritaria no conxunto das falas populares, como a propia do estándar galego configurado e socializado a partir da década de 1980, puxo en xogo un novidoso e importante factor sociolingüístico que parece estar a reorientar a secular marcha desta mudanza. Desde hai un tempo, a variante seleccionada para estes plurais no estándar galego vai sendo incorporada aos repertorios lingüísticos de certos falantes con estudos e con fasquía urbana, de tal xeito que nalgúns medios estes plurais terminados en -is van entrando en variación contextual coa solución popular converxente coa do español (animales). Por outra parte, os plurais do estándar dominan case por completo no galego escrito, literario ou non, publicado desde a década de 1980 ata hoxe.

No contributo que vou presentar estudo con detalle a evolución desta mudanza lingüística desde a época da entrada en escena do galeguismo (arredor de 1840) ata a actualidade. Nel propóñome explicar como, fronte ás tendencias populares,

4 Na décimo oitava edición destas Normas, de 2003, substituíuse "e limpo de canto de espúreo hai incrustado na fala viva" por "e limpo de canto de alleo innecesario hai incrustado na fala viva" (p. $11)$. 
se alzaron durante este tempo dous factores que promocionaron distintas solucións alternativas libres de toda sospeita de seren españolismos:

1. O purismo lingüístico, máis ou menos acentuado segundo as épocas pero propio en xeral de todo o cultivo literario do galego desde mediados do século XIX ata a actualidade.

2. A elaboración e socialización do estándar galego a partir da década de 1980, que asumiu o purismo descastelanizador como o primeiro dos seus principios inspiradores.

As fontes de estudo que sometín á análise foron, dunha parte, unha ampla representación de traballos dos séculos XIX, XX e XXI que, guiados pola intención de describir a lingua galega ou de prescribir sobre o seu correcto uso, achegan información de interese para quen queira trazar a liña evolutiva desta variable morfolóxica galega nos últimos cento sesenta ou cento setenta anos, aproximadamente; trátase de gramáticas sincrónicas e diacrónicas, propostas normativas e traballos de investigación de diverso tipo. Alén disto, analicei o comportamento desta variable en textos, literarios ou non, escritos entre 1840 e a actualidade. A meu parecer, a ponderación dos datos extraídos destes dous grandes tipos de fontes permite realizar con suficientes garantías unha descrición da moderna liña evolutiva desta variable morfolóxica tanto na lingua oral formal e informal coma na escrita. Como veremos, para facer esta descrición resulta moi útil distinguir estas tres dimensións da actividade lingüística (lingua oral formal, lingua oral informal e lingua escrita), dimensións que, en última instancia, creo que poderían presentarse como soamente dúas: a lingua da proximidade entre emisor e receptor (basicamente oral) e a lingua da distancia (oral ou escrita).

Cómpre advertir que, aínda que o obxecto deste artigo é exclusivamente o de analizar a liña evolutiva desta mudanza nos nomes polisílabos e oxítonos, tomei en consideración os datos relativos ao comportamento dos plurais dos monosílabos que puidesen achegar información complementaria de relevancia.

\section{Datos das fontes metalingüísticas}

As variantes da desinencia para a formación destes plurais que detectei nestas fontes foron as seguintes: 1) $-s$, con supresión do - $l$ final do singular; 2) -is, coa mesma supresión; 3) -es, coa mesma supresión; 4) -es, sen tal supresión; e 5) -s, sen tal supresión. 


\subsection{Gramáticas sincrónicas}

Aqueles autores que ata o día de hoxe se ocuparon de reflexionar sobre a tradición gramatical galega ${ }^{5}$, nacida na segunda metade do século XIX como unha faceta máis do noso Rexurdimento, conveñen en afirmar que unha parte importante das pezas que a constitúen está animada por unha vocación prescritiva -máis ou menos intensa e a miúdo explícita- que se explica tanto porque con elas os seus autores trataron de contribuír á fixación dunha variedade modélica da que carecía unha lingua durante séculos confinada case en exclusiva ao uso oral informal coma pola inexistencia de institucións ou de persoas de prestixio recoñecido que antes de 1982 fosen quen de configurar os perfís básicos dese modelo. Igualmente, os historiadores da produción gramatical galega coinciden en afirmar que moitas das obras que a configuran están imbuídas dun celo purista que impulsou os seus autores a rexeitar, non sempre con acerto, aquelas formas e construcións que ao seu parecer se inseriran no galego moderno como consecuencia da pesada influencia que sobre el veu exercendo o castelán, ou ben aqueloutras que por distintos motivos percibían como vulgares e indignas de seren usadas nos estilos formais ${ }^{6}$. Se ao prescritivismo e ao purismo que animou o traballo de moitos dos gramáticos galegos do XIX e do XX lle engadimos o feito de que ata a década de 1970 non se fixeron no noso país estudos científicos de amplo alcance sobre a variación diatópica propia do galego oral do noso tempo, comprenderemos por que nas gramáticas elaboradas durante toda esta época non atopamos descricións completas das distintas variantes operativas para a variable morfolóxica que neste traballo estudamos. Nas gramáticas máis antigas esta descrición pode faltar porque os seus autores omitiron de propósito información sobre algunhas das variantes en uso ou porque, carentes da información dialectolóxica

5 Cf., entre outros, Brea (1994), Freixeiro Mato (1998: 31-37), Sánchez Rei (2005) e Santamarina (1974).

6 Actitudes deste tipo detéctanse patentemente expresadas en obras máis antigas (especialmente, quizais, nas de Valladares e Lugrís Freire), pero tamén encontran expresión diáfana nas dúas últimas gramáticas dadas ao prelo durante o período anterior ao momento da constitución do galego como lingua cooficial de Galicia. O galego común que Carballo Calero (1966: 13) tratou de fixar definíase en relación co espazo (era aquel en que prevalecían as variantes dialectais de uso máis xeneralizado), co tempo (tratábase do galego moderno) e, finalmente, co medio social: ese "gallego común" non era o "gallego vulgar, profundamente alterado en su pureza por la erosión de la lengua oficial, y reducido en muchos casos a diferentes formas coloquiales empobrecidas. Es el gallego culto, el gallego literario, que aspira a ser un instrumento cabal de cultura, el que nos interesa". Pola súa parte, Carré Alvarellos (1967: 7-8) iniciaba a súa obra con esta advertencia: "Es nuestro criterio que, puesto que nos proponemos estudiar la Gramática Gallega, sea ésta la del antiguo idioma del Reino de Galicia, tomando como base aquellos elementos que a partir de la Edad Media han persistido hasta hoy en el lenguaje popular, y con los cuales nuestros escritores del pasado siglo XIX han reanudado una riqueza literaria que había sido truncada en el XVI". Isto era así porque a gramática de Carré non tiña unha orientación descritiva do galego moderno, senón un propósito decididamente depurador: "Los gramáticos, como los literatos, debemos procurar corregir defectos en los cuales incurre el vulgo iletrado" (Carré Alvarellos 1967: 8). 
necesaria, non poderían facela aínda que o desexasen; nas máis recentes a descrición completa falta porque, con excepcións parciais coma a de Freixeiro Mato (2000), os seus autores soamente se propuxeron facer a descrición da variedade estándar. Porén, o espírito purista e prescritivista desta nosa tradición gramatical obséquianos ás veces con xuízos interesantes sobre a orixe ou a extensión das variantes que os gramáticos condenaron, admitiron ou recomendaron.

Posto que con este traballo non pretendín facer unha especulación sobre o discurso gramatical galego, senón recoller nas obras que o constitúen información sobre un fenómeno morfolóxico dotado de variación diatópica, diastrática e diafásica, decidín acollerme aquí a un concepto laxo de gramática, e en concreto de gramática sincrónica, xa que isto me permitiría presentar conxuntamente a información recadada nun nutrido grupo de fontes de estudo. Por conseguinte, para os efectos desta investigación considerei nesta sección toda obra gramatical ou pseudogramatical que, cando menos nunha das partes que a constitúen, contivese unha exposición das regras polas que se rexe a formación do plural no galego moderno ou que, a falta disto, polo menos proporcionase datos que puidesen ser de relevancia para o meu obxecto de estudo. As obras que examinei foron as de Mirás (1864), Saco Arce (1868), Cuveiro (1868), Valladares (1970) ${ }^{7}$, Cornu (1906), Santiago y Gómez (1918), R. A. (1919), Lugrís Freire (1931) ${ }^{8}$, Carballo Calero (1966), Carré Alvarellos (1967), Álvarez / Regueira / Monteagudo (1986), Costa Casas / González Refoxo / Morán Fraga / Rábade Castiñeira (1988), Freixeiro Mato (2000) e Álvarez / Xove (2002).

\subsection{1. -s, con supresión do -I final do singular}

A utilización da variante $-s$ con supresión do - $l$ final do singular (animal - animás, papel - papés, funil - funís, español-españós, azul-azús) é a única norma que proclaman Saco Arce, Santiago y Gómez, R. A. e Carballo Calero ata a cuarta edición da súa gramática, publicada en 1974. Alén disto, é a norma a que se atén o plural da maioría dos nomes deste tipo utilizados no vocabulario e nos apéndices inseridos na gramática de Mirás (1864), na que non se explicita ningunha doutrina a este respecto: animás (pp. 72, 75, 96, 142 -2 veces-, 143), “Fusís.-Fusiles” (p. 44), infernás / mortás / criminás (p. 83 en posición de rima), mortás (p. 74), "Papés.Papeles" (p. 47), riás 'reás, a moeda' (pp. 131, 134) ${ }^{9}$.

7 Aínda que publicada en 1970, o manuscrito desta obra está datado en 1892.

8 A primeira edición desta gramática é de 1922.

9 Saco Arce (1868: 59) e Cornu (1906: 8) mencionan tamén aqués, variante do demostrativo aqueles que se utilizou por veces no galego escrito moderno e que debeu de xerarse por analoxía, xa que a forma histórica (aqueles) non é outra ca a esperable en galego como consecuencia adición do morfema $-s$ á 
Valladares, Cornu e Lugrís Freire tamén recoñeceron esta variante, mais poñéndoa en paridade con algunha outra. Valladares enunciou como norma que o plural dos substantivos oxítonos rematados en $-l$ no singular se formaba con eliminación desta consoante e adición do morfema $-s$ ou -es "segun las localidades", é dicir, con distribución diatópica:

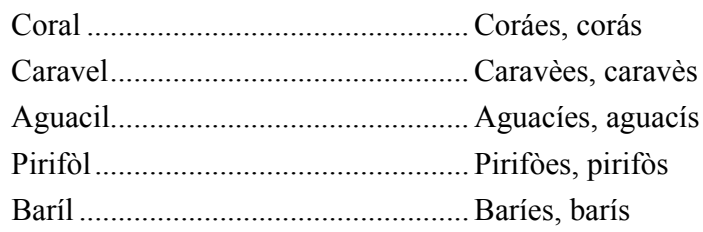

(Valladares 1970: 30-32).

Cornu non enunciou ningunha norma, pero no exemplario que ofreceu víase que nel alternaban sen criterio visible as variantes $-s,-e s,-l e s$ e $-l s$ :

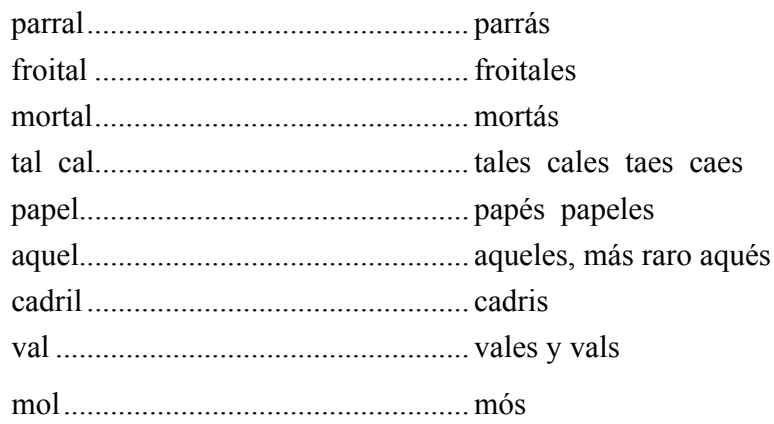

(Cornu 1906: 8).

Lugrís Freire, pola súa parte, estableceu que a variante $-s$ con supresión do $-l$ do singular era a que esixían os nomes que acaban en -al, -el ou -il (reás, papés, cadrís), mentres que os que terminaban en -ol, polisílabos ou monosílabos, pedían -es con mantemento do - $l$ (caracoles, foles). Alén disto, este observador reparou na alta frecuencia desta variante na toponimia (en concreto, na terminación -ás), poñendo así sobre a mesa un dato certo que, aínda que el non chegase a dicilo, apuntaba cara á conclusión de que esta opción gozara no pasado dunha ampla extensión diatópica:

\footnotetext{
base singular ocasionada pola actuación regular das regras de paso fonético do latín ao noso romance: aquele (<*ACCU-ILLE). Aquel, solución rexistrada tamén no galego medieval, foi o resultado dunha tardía apócope do $-e$ átono final.
} 
"Nos toponímicos atópanse moitas formas en ás, como de Cañal, Cañás; de Cerval, Cervás; de Casal, Casás" (Lugrís Freire 1931: 23).

Finalmente, varios autores da segunda metade do século XX só recoñeceron esta variante en excepcións que se apartaban da regra que describiron para o que eles consideraban galego exemplar ou, despois de 1982, galego estándar. Do meu punto de vista, estas excepcións non son máis ca reliquias de sincronías pasadas en que este procedemento de formación do plural, caduco nas últimas décadas do novecentos, aínda gozaba de gran vitalidade. Carré Alvarellos (1967: 48) contempla as excepcións xeneralizadas de reás, papés e cadrís e a dialectalmente circunscrita de pernís ${ }^{10}$, mentres que Álvarez, Regueira e Monteagudo (1986: 67) e Freixeiro Mato (2000: 49) só mencionan reás. Con todo, Freixeiro especifica que tal solución, que el cataloga como "patrimonial centro-occidental" e usada "na fala e na lingua literaria", convive "coa oriental e común reais".

O normal é que nestas gramáticas os monosílabos acabados en $-l$ sexan excluídos da relación de formas que toman esta variante para a formación do plural, pero merecen ser rescatadas as informacións que sobre este particular nos dan Cornu e Carballo Calero.

Como vimos anteriormente, no seu apéndice gramatical Cornu incluíu, sen explicacións de ningún tipo, o excepcional caso de mós como plural de mol. Trátase dunha variante que descoñezo e da que o Tesouro Informatizado da Lingua Galega (TILG) non ofrece ningún testemuño. Por tanto, teño serias dúbidas sobre a autenticidade da súa existencia ${ }^{11}$.

Ata a sétima edición da súa gramática, Carballo Calero mantivo que para o plural dos monosílabos o uso común prefería a variante -es sen eliminación do - $l$ do singular tanto en substantivos coma en adxectivos e pronomes (mal-males, fol-foles, calcales), mais en nota de rodapé ofrecía información importante sobre a permanencia de vestixios da antiga solución con $-s$ e sen $-l$ :

10 Como variante de perniles, pernis só a rexistra en Mañón, Becerreá, Ourense capital, O Carballiño e Maside (Carré Alvarellos 1967: 201).

11 Cornu (1906: 7) declarou o seguinte sobre os materiais que empregou para a elaboración do seu apéndice: "En su elaboración he tenido en cuenta la excelente Gramática Gallega de Juan A. Saco Arce, publicada en Lugo en 1868. Algunos datos preciosos suplementarios me los proporcionó la lectura de considerable número de modernos textos gallegos, publicados en su mayor parte, en la Biblioteca Gallega de La Coruña". Mós non aparece na gramática de Saco e, canto á posibilidade de que aparecese nalgún dos textos modernos que Cornu manexou, non estou en condicións de negala, aínda que o feito de que o TILG non a recolla me move a dubidar dela. 
Aun en los monosílabos se dan las formas más evolucionadas, con caída de la - $l$ final al convertirse en - $l$ - intervocálica por agregación del sufijo -es, cuya vocal es asimilada por la que en el singular precede a la - $l$. En una de las versiones de la Relación do suceso da morte do Mariscal Pardo de Cela, de principios del siglo XVI, se lee tas 'tales', y en una décima anónima de 1820 , fos 'fuelles, pulmones, entrañas'; si bien hoy lo común es decir y escribir tales y foles (Carballo Calero 1966: 92, n. 6) ${ }^{12}$.

Máis adiante, noutro capítulo da gramática, inseriu a seguinte nota a propósito do interrogativo e relativo cales:

Las formas caes, cas son arcaicas o locales. Cual, cuales/cuaes/cuás son hoy sentidas como castellanismos, portuguesismos o arcaísmos (Carballo Calero 1966: 134, n. 56).

Esta nota ampliouse na sétima edición no sentido que máis adiante expoñeremos, mais en todo caso sen modificar a doutrina referente a cas ou cuás, variantes ás que na pasaxe que acabo de transcribir semellan corresponderlles as etiquetas de arcaísmos ou localismos, é dicir, de antigas formas xa en claro proceso de recesión que poderían permanecer en uso só en esporádicos, escasos e illados falares locais.

\subsection{2. -is, con supresión do -l final do singular}

O emprego da variante -is con supresión do - $l$ final do singular (non aplicable no galego moderno aos nomes oxítonos que no singular terminan en -il, por coñecidas razóns de desenvolvemento fonético diacrónico: barriles $>$ barries $>$ barriis $>$ barrís) non foi declarado de regra por ningún gramático antes da cuarta edición da gramática de Carballo Calero, datada en 1974:

Si el singular termina en $-l$, ese fonema se sustituye por -is:

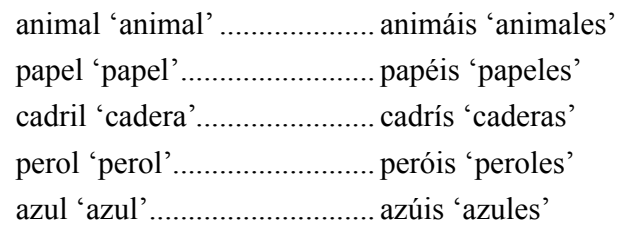

(Carballo Calero 1974: 160).

12 Para outros rexistros de tas 'tales' en textos de principios do século XIX cf. Mariño Paz (2003: 170). 
Deste xeito, Carballo abandonaba a súa primixenia predilección polo plural con supresión de $-l$ e adición de $-s$ (animás) e apostaba por aquel que xa postulara nas normas morfolóxicas da Real Academia Galega de 1971, das que fora o principal inspirador e das que axiña falaremos. Sucedía isto nun momento avanzado do proceso de elaboración non planificada da variedade estándar do galego moderno, cando ao impulso purista que o viñera animando desde o século XIX se lle empezaba a unir, logo da incorporación da investigación sobre a lingua galega á Universidade de Santiago de Compostela na década de 1960, un maior coñecemento da súa variación diacrónica e diatópica. Con efecto, xa na primeira edición de 1966 sinalara Carballo que os plurais do tipo de animais, ademais de seren formas xeradas no idioma antigamente, permanecían en uso en zonas do leste do dominio lingüístico galego e foran tamén utilizadas xunto a outras opcións por Rosalía de Castro, o clásico indiscutible da nosa literatura contemporánea:

La forma histórica del plural de los nombres terminados en $l$ es la que añade -es al singular, suprimiendo la $l$ : sinaes 'señales', mantees 'manteles', catasoes 'girasoles'. En el siglo XV la vocal del sufijo es asimilada por la tónica de la base, resultando las formas del tipo estadaas 'estadales', barriis 'barriles', españoos 'españoles', que se resuelven en las modernas con una sola vocal larga. Pero el gallego antiguo conoció también la debilitación en $i$ de la $e$ del sufijo, que se conserva hoy dialectalmente: nogáis 'nogales', españóis 'españoles', especialmente en la Galicia extremooriental y el habla del Bierzo. Es la solución portuguesa moderna. Rosalía también la conoce: mortáis 'mortales', lo mismo que la que mantiene -es: azúes 'azules', y la que añade simplemente $-s$ : frols 'flores' (Carballo Calero 1966: 91, n. 6).

Canto aos monosílabos, Carballo (1979: 166-167) mudou de posición na sétima edición da súa obra, na que deixou a un lado o que defendera anteriormente (o uso do morfema -es con mantemento do -l: males, foles, cales) para abrazar unha norma expresada de forma algo confusa mais na que se apreciaba unha vontade inequívoca de achegarse ao portugués a custa de se distanciar do uso popular e mesmo do uso daquela común na lingua escrita ${ }^{13}$ :

-es con conservación do - $l$ empregaríase cos "nombres y pronombres terminados en -le [e os seus compostos], en los que esa $l$ era doble en el étimo, que se usan a veces con la -e apocopada": vales, eles, aqueles, meles, foles, pirifoles; igualmente, o "uso" xustificaría a aplicación desta regra a "algún

13 Verbo disto, é ben elocuente que na sétima edición da súa obra o autor mantivese unha observación sobre os monosílabos que estaba xa na primeira: "hoy lo común es decir y escribir tales y foles" (Carballo Calero 1979: 167). 
monosílabo terminado en $-l$ que no la tenía duplicada en el étimo", caso para o que só ofrecía o exemplo de males;

-is con eliminación do - l utilizaríase nos monosílabos sen /l:/ (longo) no étimo; mais o emprego deste segundo alomorfo, contraditorio sen xustificación declarada co dito anteriormente para males, só se exemplificaba co caso de tais, dándose ademais a circunstancia de que esta regra se establecía case furtivamente, nunha fugaz referencia case perdida no interior dunha nota de rodapé: "hoy lo común es decir y escribir tales y foles. Pero la normativa pide tais en el primer caso y foles en el segundo, según la simplicidad o duplicidad de la $l$ en el étimo" (Carballo Calero 1979: 167).

Antes destes cambios de posición na obra do académico e catedrático da universidade compostelá, só atopamos dúas referencias pasaxeiras ao emprego da variante -is en dúas exposicións gramaticais do século XX que a catalogan como arcaica ou antiga. Santiago y Gómez (1918: 148-149) reparou na condición de arcaísmo do monosílabo cais, para o que no galego falado nos principios do século XX en varias comarcas de Galicia sinalou a correspondencia cales. Analogamente, Carré Alvarellos (1967: 48) deixou escrito que picheis e froixeis eran formas do pasado que se podían ler en escrituras antigas.

As gramáticas aparecidas despois da publicación das Normas da RAG e o ILG en 1982 reproducen a doutrina que a este respecto se oficializou naquel ano no relativo aos nomes oxítonos polisílabos: animais, papeis, barrís, españois, azuis son as formas canonizadas e prescritas en todas elas. No entanto, discrepan no tocante aos monosílabos, pois, mentres que as respectuosas coas Normas (Álvarez et alii 1986 e Álvarez / Xove 2002) establecen o uso de .es con preservación do - $l$ en todos os casos (cales, foles, males, meles, tales, etc.), as que teñen unha inclinación reintegracionista (de aproximación ao portugués) e se sitúan na liña que marcara Carballo Calero (Costa Casas et alii 1988 e Freixeiro Mato 2000) distinguen entre os que piden ou admiten -is ou -s sen -l (cais, tais, sais, sois; vis, de vil) e os que esixen -es con -l (males, vales, feles, meles, foles, moles, etc.).

\subsection{3. -es, con supresión do -l final do singular}

Se Valladares, como xa vimos, declarou ao final do século XIX que coraes e corás, caravèes e caravès, etc. eran variantes con distribución diatópica para a formación deste tipo de plurais, aínda varias décadas despois Carré Alvarellos (1967) acolleu o uso de -es sen - $l$ como de regra para os nomes polisílabos acabados en -al (sinaes, xornaes...) ou en -ol (arioes, rouxinoes...) no singular, mais non para os rematados 
en -el ou -il, que tomarían o morfema -es con - $l$ conservado (caraveles, funiles...) $)^{14}$. É posible que Carré fixese esta escolla porque tivese en mente formas predominantes no galego medieval e no de certos escritores do Rexurdimento decimonónico (modelos que, como xa dixemos, declarou seguir no prólogo da súa gramática), mais o certo é que este argumento non nos pode dar razón de por que ao mesmo tempo decidiu prescribir o uso de -les para os nomes polisílabos oxítonos que no singular acaban en -el ou en -il.

Certamente, os que vivimos nos inicios do século XXI contamos con fontes de información que nos permiten asegurar que xa durante o XX non gozaban os plurais do tipo de animaes de gran difusión na lingua galega oral. E, se é certo que as prescricións de Valladares e Carré poderían inducir algúns desinformados a concluír o contrario, tamén o é que xa na centuria pasada Lugrís Freire e Carballo Calero falaron con toda a clareza do carácter "arcaico" ou "histórico" dos plurais do tipo de animaes. É da responsabilidade do primeiro a seguinte observación:

No galego arcaico, o mesmo na "Crónica Troiana" que en documentos posteriores, vemos que o prural dos que acaban en al perde o $l$ e se lles añade es. Exempro: capital, capitaes; vocal, vocaes; carregal, carregaes. Sendo o a predominante no singular e tónico no prural, o e que admite neste número foi absorbido pol-o a. As formas vocás, carregás, reás, son, pois, contraiciós de vocaes, etc. (Lugrís Freire 1931: 24).

Carballo Calero (1966: 91, n. 6), como xa dixen, anotou que "la forma histórica del plural de los nombres terminados en $l$ es la que añade -es al singular, suprimiendo la $l$ : sinaes 'señales', mantees 'manteles', catasoes 'girasoles"'.

Nas gramáticas posteriores, todas publicadas de 1986 en diante e centradas na descrición da variedade estándar, xa se omite toda referencia a esta variante, que as investigacións realizadas desde a década de 1970 confirmaran como fundamentalmente antiga e só utilizada nalgunhas falas orientais do galego popular de hoxe en día.

\subsection{4. -es, sen supresión do -l final do singular}

Polo que se refire aos polisílabos oxítonos, a prescrición a favor desta variante para o plural só a atopamos, con certos condicionantes, nas obras de Lugrís e Carré. Poderiamos dicir, por tanto, que semella aparecer nas gramáticas sincrónicas tardia-

14 Esporádicos rexistros desta variante témolos nas obras de Cornu (1906: 8), na que lemos taes e caes á par de tales e cales, e R.A. (1919: 3), na que, a pesar de se prescribir o plural do tipo de animás, se utilizou en dúas ocasións vocaes. 
mente, cando a súa difusión na lingua popular xa debía de estar bastante avanzada, e desaparece delas cando, constituído o galego como lingua cooficial de Galicia, se instaura un modelo normativo animado por un espírito descastelanizador que levou a optar, neste caso, por unha variante tradicional que non podía suscitar ningún tipo de receo entre os máis puristas.

Mentres que Lugrís Freire (1931: 23-24) ditaminou o seu emprego cos nomes rematados no singular en -ol (caracoles, tirizoles) mais non, salvo excepcións como carballales e caraveles $^{15}$, cos acabados en -al, -el ou -il, Carré Alvarellos (1967: 48) seleccionouna só para os terminados en -el (caraveles, picheles...) ou -il (funiles, perniles...), coas excepcións de papés e cadrís. Así, pois, Lugrís propuxo unha regra para os nomes acabados en -ol e outra para os demais, ao paso que Carré estableceu unha norma para os que rematan en - al ou en -ol e outra distinta para os que o fan en -el ou en -il. A meu ver, estas "irregulares regras" son o lóxico resultado do feito de os autores destas gramáticas traballaren con grandes lagoas de información sobre o galego do pasado e do seu tempo e tamén cun evidente déficit de reflexión a propósito do seu labor. Alén disto, creo que traducen a súa impresión -non ratificada polas oportunas investigacións de campo e insatisfactoriamente expresada no papel- de que a mudanza que propulsaba o emprego dos plurais terminados en -les estaba máis adiantada cunhas unidades lexicais ca con outras e ía deixando no camiño reliquias ou "excepcións" que por diversas razóns se resistían a secundar a innovación ou, para dicilo con máis exactitude, que a estaban a secundar con maior morosidade. Ao paso que tras das "escepciós que o bon uso insina" de que falou Lugrís o que se albisca non é outra cousa ca o coñecido fenómeno da difusión léxica (o cambio difúndese con máis rapidez nunhas palabras ca noutras), casos coma os de reás, papés e cadrís que apuntou Carré deben contemplarse, como xa advertín noutro lugar (Mariño Paz 2003: 164-169), como os esperables vestixios deixados na súa retirada por unha norma xeneralizada no pasado pero en 1967 xa esmorecente. Máis adiante haberá que comprobar se os datos tirados de fontes literarias confirman ou non estas hipóteses.

Debémoslle a Carballo Calero (1966: 91-92, n. 6) a opinión, concordante cos datos que as investigacións dialectolóxicas nos proporcionarían moi pouco despois, de que a mediados da década de 1960 a variante -les xa era maioritaria na lingua popular: "Lo más vulgar es mantener la $l$ y añadir -es, a la castellana, especialmente cuando precede a la $l$ una vocal de la serie posterior" ${ }^{\text {"16 }}$. Porén, os

15 Así se expresou a este respecto este autor: "Os nomes que finan en $a l, e l, i l$, adoitan formaren o prural perdendo o $l$ e añadíndolles $s$. Exempros: real, papel, cadril; reás, papés, cadrís [...]. Ten moitas escepciós que o bon uso insina: Lanzal forma o prural lanzales; mal, males; carballal, carballales; caravel, caraveles, froital, froitales; val, vales; xornal, xornales" (Lugrís Freire 1931: 23-24).

16 Isto último quere dicir que Carballo Calero tiña a respecto disto unha percepción distinta da de Carré Alvarellos pero compatible coa que expresou Lugrís: a de que a mudanza a prol da solución 
rexistros desta variante xa non son raros nalgunhas gramáticas do XIX ou do XX cuxos autores, aínda que non optasen explicitamente a prol dela, aduciron de vez en cando exemplos terminados en -les. Na obra de Mirás (1864) predomina o uso de animás, mortás, etc., pero tamén se len mortales (en rima co monosílabo tales, p. 73) e ijuales (p. 105). Na de Saco Arce (1868: 268) atopamos cascabeles; na de Valladares (1970), caraveles (p. 14) e mais os castelanismos lexicais arrabales (p. 33) e andurriales (p. 33); na de Cornu (1906: 8), froitales e papeles (a carón de papés). Nas dúas gramáticas redactadas en galego pouco antes da Guerra Civil española os seus autores foron bastante escrupulosos no acatamento das regras de formación do plural que eles mesmos enunciaron nelas, mais non conseguiron evitar a infiltración dalgunhas voces con plural en -les pertencentes ao campo semántico da terminoloxía gramatical: xunto a animás (p. 6), cardinás (p. 12), finás (p. 30), etc., R.A. (1919) empregou tamén adverbales (p. 27), causales (p. 28), condicionales (p. 28), finales (p. 28), impersoales (p. 33) e persoales (pp. 13, 33), en tanto que Lugrís Freire (1931), ao lado de adverbiás (p. 34), animás (p. 99), artificiás (p. 17), cardinás (pp. 4, 29), etc., usou tamén adverbiales (p. 76), Causáles (p. 81), nasales (pp. 6, 2 veces; 185) e plurales (p. 36). O hábito de reproducir mecanicamente a terminoloxía gramatical en castelán difundida a través da escola e doutros medios (modos adverbiales, conjunciones condicionales, pronombres personales, etc.) debeu de inducir estes dous autores a incorrer nestas incoherencias.

Cos monosílabos, o uso da variante -es con - $l$ mantido estaba moi estendido xa no século XIX, pois en todas as gramáticas anteriores á sétima edición da de Carballo Calero, tanto se os seus autores se pronuncian explicitamente verbo disto coma se non o fan, recóllense como normais cales, tales, males, vales, meles, coles, foles, froles 'flores' ou soles. Canto ao cambio de posición de Carballo e á doutrina das gramáticas posteriores, remito o lector ao que dixen en páxinas anteriores.

Os substantivos compostos que teñen como segundo lexema un monosílabo debátense entre a selección da variante -es con - $l$, esperable en virtude da súa análise como unidades bimembres cun segundo elemento monosilábico, e o seu comportamento como unidades polisilábicas, evidenciado polo emprego de solucións con eliminación da consoante lateral. A primeira opción rexístrase nas obras de Saco Arce (pirifoles, pousa-foles $)^{17}$ e Carré Alvarellos (zugameles, pousa-foles) ${ }^{18}$, na sétima edición da

converxente coa propia do castelán estaba máis adiantada no caso das terminacións en -oles e en -ules.

17 Véxase en Saco Arce (1868: 33, 52).

18 Véxase en Carré Alvarellos (1967: 46, 183). 
de Carballo Calero (pirifoles) ${ }^{19}$ e nas gramáticas posteriores a esta que se ateñen á letra das Normas da RAG e o ILG de 1982; a segunda, na de Valladares (pirifòes, pirifòs $)^{20}$ e nas seis primeiras edicións da de Carballo Calero (pirifós) ${ }^{21}$.

\subsection{5. -s, sen supresión do -I final do singular}

Só nas obras de Cornu, Carballo Calero e Carré Alvarellos se encontran pasaxeiras mencións desta variante, que parece nacida do debilitamento articulatorio da vogal átona final da terminación -les: vales $>v^{2} l^{e} s>$ vals.

O primeiro dos devanditos tres autores, que elaborou o seu apéndice morfolóxico a partir da gramática de Saco e do escrutinio de textos galegos do seu tempo, apuntou vales e vals como formas posibles para o plural de val (Cornu 1906: 8). Consonte o TILG, vals foi, en efecto, unha variante moi utilizada en obras aparecidas entre 1876 e principios do século XX.

Na súa nota sobre a evolución diacrónica da variable morfolóxica que estamos a estudar, Carballo Calero (1966: 91-92, n. 6) incluíu a referencia ao feito de que na obra de Rosalía de Castro se le o plural frols 'flores'. O TILG corrobora a corrección desta afirmación, pois, ademais de noutras fontes datadas entre 1880 e 1949, frols aparece en dúas ocasións no poemario rosaliano titulado Follas Novas (1880).

Finalmente, Carré Alvarellos (1967: 201) anotou pernils e vals como variantes dialectais de perniles e vales.

\subsection{Gramáticas diacrónicas}

Explorei para este traballo as obras de García de Diego (1909: 88-90), Couceiro Freijomil (1935: 131)22 e Ferreiro (1995: 234-236), das cales só reproducirei a información que poida botar algo de luz sobre o obxecto de estudo deste artigo.

19 Véxase en Carballo Calero (1979: 166).

20 Véxase en Valladares (1970: 32).

21 Véxase en Carballo Calero (1966: 91).

22 Débese ter presente que esta obra de Couceiro é unha versión algo ampliada -e en certas pasaxes distinta- do traballo que incluíra no volume colectivo intitulado Geografía General del Reino de Galicia, publicado en Barcelona en edición do historiador Carreras Candi no ano 1926. Ora ben, o que Couceiro Freijomil dixo en 1935 verbo da formación do plural dos polisíbalos oxítonos acabados en - $l$ no singular (Couceiro Freijomil 1935: 131) era unha reprodución exacta do que xa dixera anteriormente (cf. Couceiro Freijomil (s.d.): "El idioma gallego", p. 214). Por outra parte, cómpre advertir que na redacción da parte gramatical do seu contributo Couceiro seguiu moi de cerca a gramática histórica de Vicente García de Diego, como el mesmo recoñeceu (Couceiro Freijomil 1935: 101, n. 92). 


\subsection{1. -s, con supresión do -l final do singular}

Trátase da variante que García de Diego presenta como propia de "la lengua actual" ou da lingua "moderna" (animás, painzás, pallás, papés, fusis, virís, azús, etc., exemplos aos que lles engade aqués como solución alternativa de aqueles) e tamén, significativamente, da que Couceiro sinala en primeiro lugar na súa breve exposición (sinás, tonés, cadrís, rousiñós, azús). Ao final do século XX Ferreiro catalogouna, do punto de vista diatópico, como variante central e occidental, coa singularidade do caso de -ís (infantís), solución propia de "todo o territorio".

Canto aos monosílabos, só na obra de García de Diego (1909: 100) se atopa unha alusión á rara posibilidade de se usar cas como plural do indefinido cal. Segundo este autor, as solucións empregadas "preferentemente" para este plural eran cales e caes.

\subsection{2. -is, con supresión do -l final do singular}

Para García de Diego esta era unha solución rara "en los principios de la lengua”, é dicir, no galego medieval (de cuxas fontes cita testimoyais e o monosílabo quais), e pouco usada no seu tempo, nos inicios do século XX. Ferreiro, coñecedor da investigación dialectolóxica realizada desde a década de 1970, presentouna como variante oriental e, alén disto, como a solución propia do estándar elaborado desde os anos oitenta (reais). Na liña mantida por Carballo Calero e outros autores con maior ou menor inclinación reintegracionista, Ferreiro sinalou para sales, soles, tales e cales unhas variantes sais, sois, tais e cais que, evidentemente, non tomou da fala popular contemporánea.

En 1935 Couceiro Freijomil non mencionou a existencia desta variante.

\subsection{3. -es, con supresión do -l final do singular}

García de Diego e Ferreiro coinciden en considerala unha solución antiga. O primeiro rexistrouna "en los principios de la lengua" (estadaes, cendaes, puçaes, casaes, mantees, tonees, caes, taes, etc.) e semellaba estar a referirse en exclusiva á lingua escrita do seu tempo cando a propósito dos monosílabos tal e cal afirmaba que "el antiguo plural lo emplean varios en taes y caes". O segundo só cita esta variante como "medieval".

Non hai ningunha referencia a ela na obra de Couceiro. 


\subsection{4. -es, sen supresión do -l final do singular}

Basicamente, os autores destas tres gramáticas históricas presentan esta variante como moderna, castelanizante no caso dos polisílabos oxítonos (mortales, papeles, cadriles, catasoles, azules) e libre de sospeita cando se emprega con monosílabos (tales, vales, soles...). Da exposición de García de Diego infírese que ese autor non a consideraba moi estendida nos principios do século XX, pois dicía que "algunos ${ }^{23}$ usan también plurales en ales". Ferreiro, pola súa parte, non se pronuncia respecto da súa difusión diastrática e diafásica, xa que soamente afirma que, fóra da comarca "galego-asturiana" en que non se perdeu o /1/ intervocálico, as solucións -ales, -eles, etc. "tamén se rexistran [...] por interferencia morfolóxica do español”. Couceiro, talvez inspirándose na gramática de Lugrís, apuntou que esta variante se usaba "especialmente en los nombres terminados en $o l$ ".

\subsection{5. -s, sen supresión do -l final do singular}

García de Diego presentouna como solución de moi pouco uso empregada tanto con polisílabos oxítonos (catedrals, rousiñols, etc.) coma con monosílabos (vals, sols). Couceiro mencionouna, xunto a sinales, toneles, etc., como simple alternativa á solución común do tipo de sinás, tonés, etc. Ferreiro non fala dela.

\subsection{Propostas normativas}

Das propostas normativas dadas a coñecer antes da Guerra Civil española só me referirei á publicada polo Seminario de Estudos Galegos (SEG) en 1933. A brevísima Engádega ás Normas para a unificazón do idioma galego que a mesma institución deu ao prelo en 1936 non contén nada de interese para os obxectivos que persigo neste traballo. Das propostas que se fixeron despois da guerra e antes da aparición das Normas de 1982 que foron declaradas oficiais, tiven en consideración as da Real Academia Gallega (RAG) (1970, 1971), as Bases prá unificación das normas lingüisticas do galego de 1977, as da Comisión de Lingüística da Xunta de Galicia (1980) e as da Asociación Sócio-Pedagóxica Galega (AS-PG) (1980). Canto ás Normas da Real Academia Galega e o Instituto da Lingua Galega (ILG) (1982), revisei non só a súa redacción inicial, senón tamén as súas reformas de 1995 e 2003, nas que non se introduciron mudanzas substanciais no tocante a estes plurais. Finalmente, explorei tamén a resposta reintegracionista que ás Normas oficiais lle deu a Associaçom Galega da Língua (AGAL) en 1983, completada en 1989 cunha segunda edición corrixida e aumentada.

23 O emprego da letra itálica con esta palabra é da miña responsabilidade. 
Os métodos de aprendizaxe do ILG titulados Gallego 1 (1971), Gallego 2 (1972) e Gallego 3 (1974) funcionaron durante parte da década de 1970 como unha referencia normativa que nalgunhas cuestións se apartaba do que a RAG ditaminara en 1970 e 1971 . Por esta razón, tamén incluín nesta alínea as informacións que sobre a variable morfolóxica que aquí estudo extraín das primeiras edicións de Gallego 1 e de Gallego 2 (Instituto de la Lengua Gallega 1971, 1972), que en entregas posteriores foron sometidas ás modificacións necesarias para adaptalas ao modelo normativo que acabou prevalecendo.

\subsection{1. -s, con supresión do -l final do singular}

Esta é a solución proposta para os polisílabos oxítonos polo SEG en 1933 (casás), e aínda a que a RAG utilizou na redacción do seu opúsculo ortografíco de 1970 (culturás, vocás, etc.), no que esta institución non se pronunciou explicitamente verbo desta variable morfolóxica. Así mesmo, é a que o ILG recoñeceu no Gallego 1 (1971) e no Gallego 2 (1972) só para os substantivos cadrís e reás, que presentaba como excepcións que escapaban á regra xeral de formar estes plurais coa adición do morfema -es e o mantemento do -l (animales).

Non hai prescrición a favor desta variante en ningún dos textos publicados posteriormente.

\subsection{2. -is, con supresión do -l final do singular}

Para os polisílabos agudos, esta é a solución (animais, papeis...) que en 1971 propugnou a RAG, institución que, no entanto, un ano antes empregara a variante animás na redacción do seu folleto ortográfico de 1970. ¿Cales foron as razóns que motivaron esta mudanza de orientación normativa, que non soamente rompía co que anteriormente fixera a mesma RAG e coas normas do SEG de 1933, senón tamén, como xa vimos, coa xeneralidade do discurso gramatical galego que arrincara en 1864 ? Na argumentación que acompañaba a proposta da Academia do ano 1971 manexábanse os seguintes tres argumentos para motivala: a) animais é unha variante viva no galego moderno (característica das terras orientais, mais non "violenta" para ningún galegofalante); b) permite a harmonización co portugués; e c) ten sobrada tradición na documentación histórica $^{24}$. Aínda que isto non se explicitaba, desta explicación podíase inferir que, pola súa parte, a solución animás xa non gozaba daquela do respaldo dun uso

24 "A solución que recomendamos, característica hoxe do galego oriental, non resulta violenta para ningún galego, coincide co portugués e está abonada históricamente" (Real Academia Gallega 1971: 25). 
popular estendido e tamén que, como é obvio, a súa adopción non propiciaba un achegamento ao portugués.

Esta variante foi tamén propugnada nos textos posteriores, coas únicas excepcións do Gallego 1 (1971) e do Gallego 2 (1972), dúas obras en que o galego que se ensinaba estaba moi achegado ao uso popular predominante e en que a intervención purista se aplicaba con moita mesura. Nas Bases de 1977, ao argumento da harmonización co portugués agregáronselle, para defender a solución rematada en -is, o de que era máis "arcaizante", o de que estaba "plenamente recuperada" "no galego escrito dos últimos tempos" e, diafanamente expresado, o de que a terminada en $-s$ e sen $-l$ era xa unha opción en avanzado estado de decadencia:

Deses dous morfemas, o único produtivo hoxendía é -is, mentres que - $s$ só aparece en certas palabras, tres ou catro todo o máis en cada lugar, das acabadas en -al [...]. Ambalas dúas son formas galegas, pro a primeira é mais produtiva. Téñense rexistrado formas como españois, caracois, artificiais, pro non españós, caracós, artificiás (Bases, p. 30, n. 5).

Na argumentación das Normas da RAG e o ILG (1982: 52) insistiuse moito na idea de que, sendo tanto animás coma animais variantes galegas tradicionais, a primeira delas presentaba o inconveniente de se achar xa nun avanzado estado de abandono:

En canto á extensión xeográfica, a solución animais ocupa unha área moi restrinxida, na parte máis oriental de Galicia, pero ten ó seu favor que dentro dela segue sendo un plural productivo (caracois, artificiais, etc., pódense oír dentro dela). A solución animás debería ocupa-lo resto do territorio, pero só se oe en palabras illadas (como reás ou cadrís) e ás veces mesmo sen continuidade xeográfica (en puntos illados pódese recoller animás, ou toxás, ou currás, e poucas máis). A solución animás foi suplantada case totalmente por animales, de tal maneira que hoxe é imposible caracós, españós, nacionás, fusís, etc.; esta mesma suplantación dáse no caso de animais, pero en menor medida.

No tocante ao plural dos monosílabos, só as propostas da Comisión de Lingüística da Xunta de Galicia (1980) e da AGAL (1983, 1989) propugnaron, con diferentes alcances, o emprego desta variante. Na primeira delas unicamente se defendeu esta opción no caso de tais, mentres que na segunda, ademais de a tais, aplicóuselles a mesma regra a quais, aos substantivos sais e sóis e mesmo a méis (alternativa de meles). En todo caso, é evidente que o que motivou estas propostas non foi o empeño de rescatar para o estándar algunhas formas vivas daquela na lingua popular, senón a vontade de intervir conscientemente sobre o instrumento lingüís- 
tico para depuralo de variantes que se estimaban castelanizantes (cales, tales...) e canonizar, no canto delas, as que son propias do portugués e, nalgún caso, as que contan tamén con precedentes rexistrados no galego medieval (quaes, taes, maes). Que tal tipo de solucións xa non goza de uso no moderno galego popular é un argumento que se utilizou para desbotalas nas Bases de 1977 e nas Normas da RAG e do ILG de 1982.

\subsection{3. -es, con supresión do -l final do singular}

Ningunha das propostas exploradas apoiou esta opción, que só nas Bases de 1977 e nas Normas da RAG e do ILG se menciona como variante diatópica moi minoritaria que "nalgures" alterna con -is (animais ou animaes).

\subsection{4. -es, sen supresión do -l final do singular}

Para os polisílabos oxítonos a defensa desta variante encóntrase nos métodos de aprendizaxe Gallego 1 e Gallego 2, onde con todo se recoñeceron as excepcións de reás, cadrís e adrais, das que se aseguraba que conservaban unha alta frecuencia de uso popular. Os argumentos en que esta decisión se baseou explicounos do seguinte xeito García:

Coidamos que o plural dos nomes rematados en $-l$ debe facerse engadindo o morfema -es ó singular. Non se nos oculta que na Edade Media desaparecía regularmente este $l$. Nembargantes, a tendencia moderna da lingua é a restauración deste sonido consonántico, cousa non infrecuente e, polo tanto, non sospeitosa de castelanismo. Esta tendencia é moi clara nos monosílabos e nos polisílabos rematados en -ol, -il, -el e-ul: alcoles, fusiles, papeles, baúles.

Os casos máis dubidosos serían os dos rematados en -al. Tamén estes están sufrindo unha nivelación analóxica de grande intensidade: catedrales, animales, cristales, especiales... Somentes palabras de uso esclusivo en plural resisten a esta nivelación (reás, adráis). Nós mantemos esta distinción.

Polo tanto, visto que esta tendencia responde a unha evolución da lingua, que na literatura ten un uso maior que calquera outra forma de plural, que está moi estendida popularmente e que as gramáticas non coinciden, non dubidamos en adoutar este esquema unificador (García 1971: 139-140).

Tórnase evidente que nesta explicación se investía de gran importancia o feito de que este tipo de plurais acabados en -les representase "a tendencia moderna da lingua", que mesmo os nomes terminados en -al no singular estivesen sumándose con "grande intensidade" a ela, que esta variante estivese xa entón, 
en definitiva, "moi estendida popularmente". Esta era, pois, sen discusión, a dirección dominante desta mudanza morfolóxica na lingua popular da segunda metade do século XX.

Na mesma idea abundaron anos despois as Bases, onde animales foi declarada como alternativa admisible de animais:

Amais das citadas, son tamén admisibles as formas animales, dificiles, posíbeles..., moi xeneralizadas na fala. Estas formas son sospeitosas de castelanismo, pro tamén puideran se-lo resultado dunha recuperación do $l$ a partir do singular, ou as dúas cousas á vez, o que explicaría o enorme éxito que tiveron nos últimos tempos, ata facer recuar ás outras formacións.

Se ben, como decimos, son admisibles tanto animais como animales, coidamos que debe dárselle preferencia á primeira por representa-la nosa tradición (Bases, 30-31).

Igualmente, a idea do alto grao de difusión que nestes anos atinxira esta variante expresouse, como antes vimos, nas Normas da RAG e do ILG, nas que se afirmaba que "a solución animás foi suplantada case totalmente por animales" e que o mesmo estaba a acontecer, aínda que en menor medida, a custa de animais.

O acatamento do uso popular está na base da selección da variante -les para os plurais de todos os monosílabos (vales, cales, meles...) en todas as propostas examinadas menos na da Comisión de Lingüística da Xunta de Galicia de 1980 e na da AGAL $(1983,1989)$. Os textos que se pronunciaron sobre o plural dos nomes compostos cuxo segundo elemento é un monosílabo (Real Academia Gallega 1971, Instituto de la Lengua Gallega 1972, Comisión de Lingüística da Xunta de Galicia 1980, Real Academia Galega / Instituto da Lingua Galega 1982) fixérono unanimente tamén a favor desta variante: cartafol - cartafoles, chuchamel - chuchameles, pirifol pirifoles, etc.

\subsection{5. -s, sen supresión do -l final do singular}

Esta variante non se menciona en ningunha das propostas normativas exploradas.

\subsection{Traballos de investigación}

Nesta sección presentarei algúns datos tirados dunha selección de traballos que conteñen información sobre a variación diatópica, diastrática e diafásica no galego falado e escrito entre a primeira metade do século XIX e o ano 2000, aproxi- 
madamente. Apuntamentos sobre a evolución da variable morfolóxica que estou a estudar na lingua do XIX tomeinos das obras de Mariño Paz (2003: 164-170), Freixeiro Mato / Sánchez Rei / Sanmartín Rei (2005: 273-276) e Sánchez Rei (2006: 186-189). Información sobre a súa situación na última década do XX recadeina nas contribucións de Dubert García (1999: 93-96; 2002). Dos mapas do Atlas Lingüístico Galego (ALGa 2) e da contribución de Fernández Rei (1990: 6465) tomei a fotografía do estado evolutivo desta variable entre a década de 1970 e as postrimerías do século, e non me resultou difícil inferir de tal fotografía e do seu contraste con outros datos xa coñecidos a evolución que a este respecto se deu entre finais do XIX e finais do XX. Finalmente, tamén tiven en conta as achegas de Regueira (1999, 2003, 2005).

\subsection{1. -s, con supresión do -I final do singular}

Os traballos de investigación consultados coinciden en afirmar que esta variante gozou dun elevado nivel de uso na lingua literaria decimonónica que probablemente se correspondía coa súa conservación aínda moi difundida na lingua popular da Galicia centro-occidental, é dicir, na da maior parte do territorio galegofalante. As fontes escritas da primeira metade do oitocentos amosan que esta regra aínda era daquela produtiva cos neoloxismos: constitucionás, servís 'partidarios do absolutismo', etc. Con unidades lexicais como reás, plural de real 'unidade monetaria', e papés o seu mantemento maniféstase con particular firmeza na documentación decimonónica conservada.

No entanto, o Atlas Lingüistico Galego (ALGa 2: mapas 71, 72, 73, 74, 75, 76, 77), Fernández Rei (1990: 65) e Dubert García (1999: 96) mostran que no derradeiro cuartel do século XX esta variante estaba xa próxima a sucumbir ante o asoballante progreso que nas décadas anteriores viñera coñecendo -les na lingua popular. Quedaban daquela, con todo, certas unidades lexicais en que os tradicionais plurais centro-occidentais rematados en -ás, -és, etc. aínda conservaban unha desigual frecuencia de uso. Así, currás gozaba de máis vitalidade ca ladrás ou reás, que por súa vez semellaban máis estendidos ca candís ou cadrís; e todos estes plurais se usaban daquela máis ca catedrás e fusís. Como ben se sabe, isto é algo que se observa en moitos procesos de cambio lingüístico: é frecuente, mesmo habitual, que as distintas unidades susceptibles de resultaren afectadas por el non se transformen simultaneamente, senón con ritmos distintos e con desigual resistencia ao avance da innovación. As innovacións esténdense por medio de procesos de difusión léxica que non alcanzan nin transforman todas as palabras ao mesmo tempo nin coa mesma rapidez e que mesmo poden deixar que algunhas delas se libren do seu influxo. 
Neste caso, dá a impresión de que a variante tradicional resistiu máis firmemente o embate da innovación terminada en -les en dous casos: 1) co vocabulario elemental máis vinculado ás formas de vida tradicionais das clases populares: animás, currás, ladrás (plural de ladral), reás, papés, cadrís (plural de cadril), candís, fusís, etc.; 2) cos nomes utilizados a miúdo ou case en exclusiva en plural (reás, papés, etc.), con algúns dos cales mesmo puido chegar a quedar escurecida a existencia da base singular (caso, por exemplo, de cadril 'cada un dos ósos da cadeira' ${ }^{\prime 2}$ e de ladral < LATERALE 'cada unha das táboas laterais do carro galego tradicional que serven para suxeitar a carga').

Para o monosílabo tal aínda temos documentación minoritaria mais non desdeñable de tas nas fontes escritas das primeiras décadas do XIX. Con todo, non cabe dúbida de que o uso maioritario con todos os monosílabos na lingua popular dos dous últimos séculos foi, con contadas excepcións, o da variante -es con - $l$ mantido.

\subsection{2. -is, con supresión do - I final do singular}

É unha variante minoritaria na lingua literaria decimonónica, na que, cando aparece, adoita facelo en obras cunha evidente coloración dialectal oriental ou, en todo caso, abertas á incorporación de variantes con esta procedencia. É o que ocorre coas Proezas de Galicia (1810) de José Fernández Neira, onde lemos papeis, e mais cos Ensayos poéticos en dialecto berciano (1861) de Antonio Fernández y Morales, nos que achamos ráis 'reás, reais'.

Consonte o ALGa 2 (mapas 71, 72, 73, 74, 75, 76, 77) e Fernández Rei (1990: 65), nas décadas finais do século XX esta variante seguía sendo produtiva en moitos puntos do centro e o sur do leste do territorio galegofalante, ao paso que a zona asturiana, onde historicamente non se perdeu o /1/ intervocálico, mantiña os seus plurais autóctonos do tipo de animales.

Logo de ser seleccionada para a variedade estándar nas Normas da RAG e do ILG declaradas oficiais en 1983 e axiña difundidas a través de diversas vías ata o conxunto da poboación, cara ao final da década pasada esta variante parecía empezar a comportarse xa como unha innovación propagada "desde arriba". No seu estudo da fala do Santiago de Compostela finisecular Dubert García (1999: 94-95) encontrouse con "falantes con estudios e con abundantes trazos lingüísticos de fasquía urbana" que, situados nun contexto formal, utilizaban esta variante (azuis, espirituais,

25 Repárese na seguinte pasaxe dos Contos galegos d'antano e d'hogano (1920) de Manuel Vidal Rodríguez, onde, significativamente, cadrís foi usado como substantivo en singular, xa que o seu $-s$ non se interpretou como desinencia de plural, senón como consoante final do lexema: "se sei que volves a dar con el un pío, co mallo de mallar creboche un cadrís” (cf. TILG). 
municipais...) en alternancia coa popular -les. Ao seu parecer, isto demostraba "que algúns procesos morfolóxicos da lingua estándar comeza[ba]n a estenderse nalgúns medios sociais e a entrar en variación contextual coas formas populares, de modo que o galego estándar comeza[ba] a compartir co castelán o papel de lingua teito e a competir con el na creación de formas de prestixio". Para estes falantes, a utilización da variable animales - animais funcionaba xa como un marcador de status. Non hai motivos que nos induzan a pensar que o que Dubert sinalou para o dialecto de Santiago de Compostela non se estivese a producir, con maior ou menor intensidade, noutras zonas do país. Cara a isto apuntan, precisamente, algunhas observacións realizadas nos últimos anos polo propio Dubert García (2002: 22-23) e por Regueira (1999: 865, 867), quen ademais sinala o esperable uso case exclusivo da variante normativa animais na lingua escrita e publicada de 1980 en diante (cf. Regueira 2003: 210; 2005: 81).

\subsection{3. -es, con supresión do -l final do singular}

Trátase dunha variante moi minoritaria na lingua escrita decimonónica e, con certeza, moi minoritaria tamén na lingua oral coetánea. Para o período final do século XX, o ALGa 2 só a amosa nalgúns puntos do leste, case sempre en concorrencia coa variante -is con -l suprimido (currais - curraes, catedrais - catedraes, reais - reaes, etc.) ou coa variante con-les (reales - reaes).

\subsection{4. -es, sen supresión do -l final do singular}

É unha variante bastante frecuente na lingua escrita decimonónica, mais aínda non maioritaria á altura de 1840. Parece que, mediado o século XIX, non se chegara aínda ao punto de se estar a producir unha rápida expansión desta variante innovadora, cousa que debeu de acontecer máis tardiamente, a son co veloz avance do coñecemento e o uso do castelán que se deu en Galicia sobre todo no século XX.

De acordo co ALGa 2 e con Fernández Rei (1990: 65), esta é a variante maioritaria no galego popular de finais do novecentos, imposta xa case por completo á solución animás no centro e no oeste do territorio e tamén utilizada en concorrencia con animais naquelas zonas do leste onde se mantén estoutra variante tradicional. Ao final da década dos noventa, Dubert García (1999: 93-94) concordaba con esta apreciación.

Polo que atinxe aos polisílabos oxítonos, esta variante innovadora debeu de progresar máis velozmente cos neoloxismos (faroles en lugar de farós, chavales no canto de chavás...), cos castelanismos flagrantes (Madriles por Madrid) e co léxico máis vencellado co mundo e a ideoloxía oficial do estado-nación español en proceso de 
construción desde a primeira metade do XIX (españoles en vez do antigo españós). Todo este léxico contou con axentes propagadores tan eficaces coma o ensino (cada vez máis estendido), a prensa escrita, os modernos medios de comunicación audiovisual ou o castelán falado nas vilas e cidades polas persoas influentes.

Esta foi a variante máis frecuentemente utilizada para os plurais dos monosílabos e das palabras compostas cuxo segundo elemento é un monosílabo no galego popular e mesmo no galego escrito dos dous últimos séculos ${ }^{26}$.

\subsection{5. -s, sen supresión do -l final do singular}

É unha variante infrecuente no galego escrito dos séculos XIX e XX. Segundo o ALGa 2 e Fernández Rei (1990: 65), nos últimos tempos aínda se usa nalgúns falares populares do occidente, sobre todo en puntos da provincia da Coruña en que esporadicamente se oen currals, catedrals, etc.

\section{Datos das fontes literarias}

Se os datos expostos na sección anterior permiten recompoñer, polo menos parcialmente, a andadura desta mudanza lingüística no galego oral, sobre todo popular, e tamén no galego escrito de case os últimos dous séculos da historia de Galicia, é evidente que os que deseguido se van presentar achegan información sobre o comportamento desta variable morfolóxica no moderno galego escrito. Ora ben, coido que colateralmente pode derivarse desta información algunha hipótese non demasiado desencamiñada a propósito do que a respecto disto debeu de ocorrer nos contextos -non moi numerosos antes da década de 1970 e certamente raros no século XIX e nos inicios do XX-en que se fixese un uso oral formal, esixente ou pulido da lingua galega. Ben é certo que a lingua escrita non é unha fiel e mecánica transcrición da lingua falada, e tamén que sería inxenuo supoñer que nas súas alocucións os bos oradores utilizan un rexistro calcado do propio dos textos escritos. Con todo, sabemos que tanto no caso do galego coma no doutros idiomas do noso contorno prevaleceu durante moito tempo, e a meu ver prevalece aínda, a idea de que o discurso oral formalizado debe aproximarse no posible ás formas dos textos escritos máis selectos, máis refinados, máis elaborados (cf. Regueira 1999, 2003, 2005), xa que se pensa, e non sen razón en bastantes ocasións, que fala mellor o que mellor escribe, ou que a falar ben se aprende lendo e escribindo con frecuencia

26 Para o galego popular de finais do século XX cf. ril-riles e cal-cales (ALGa 2, mapas 79 e 369) e tamén chuchameles (ALGa 2, mapa 78). 
e corrección. Por este motivo, creo que a observación do ocorrido a este respecto no galego escrito dos últimos tempos pode permitirnos que, coas debidas cautelas, elaboremos algunha hipótese do que paralelamente puido ir acontecendo no galego utilizado en actos públicos de carácter político, cultural ou académico.

Coa brevidade esixible nunha contribución coma esta, aproximareime a esta cuestión por medio de nove ilustracións que amosan as porcentaxes de uso alcanzadas polas distintas variantes dos plurais de oito nomes polisílabos oxítonos e do identificador monosilábico tal no galego escrito entre 1840 e 2002. Como o que aquí nos importa é só o comportamento da variable morfolóxica que estamos a analizar, agrupei nunha soa entrada todas as variantes fonéticas de cada palabra que comparten a mesma variante para o morfema de plural: así, por exemplo, reás, reiás, raás, raiás, riás e rás presentareinas unificadamente baixo a entrada reás. Os datos necesarios para elaborar estas ilustracións recadeinos no Tesouro Informatizado da Lingua Galega (TILG), servido gratuitamente polo Instituto da Lingua Galega a través da Internet. A propósito disto é necesario advertir que entre os textos de entre $1612 \mathrm{e}$ 2002 que se incluíron no TILG se encontran algunhas gravacións orais que proceden principalmente de memorias de licenciatura e de teses de doutoramento realizadas ao final do século XX; na análise que deseguido vou facer esta circunstancia deberá ser ponderada en diversos casos.

Tomo o ano 1840 como data de inicio desta pescuda porque os datos das décadas anteriores xa os ofrecín e estudei en dous traballos previos (Mariño Paz 2003, 2004) e tamén porque hoxe en día se considera que foi arredor de 1840 cando botou a andar o movemento galeguista, que animou cun crecente espírito purista e descastelanizador o cultivo do galego. Pola súa parte, 2002 é o último ano para o que na actualidade contén información o TILG.

Distinguín catro grandes etapas neste período de 163 anos. A primeira (1840-1915) correspóndese con toda a época anterior á irrupción en escena do nacionalismo galego. Nesta etapa o purismo lingüístico, aínda non sendo descoñecido, non chegou a atinxir a intensidade que si alcanzou entre 1916 e 1936, cando o cultivo do idioma galego, promovido en boa medida-mais non só-polo nacente nacionalismo, adoitou facerse con esixencias de intelectualización, desruralización e descastelanización. Nos anos posteriores á instauración do franquismo en Galicia en xullo de 1936 foise conseguindo - moi devagar ata a década de 1950- unha recuperación do galego escrito, recuperación que a partir dos anos sesenta se fixo xa en consonancia coas orientacións que naqueles tempos foron proporcionando gramáticas e propostas normativas. Por fin, a publicación das Normas ortográficas e morfolóxicas do idioma galego (1982) da RAG e o ILG marcou o inicio do proceso de estandarización xa planificado. 


\section{1. -s, con supresión do -l final do singular}

É unha variable con desigual nivel de uso antes de 1982: moi alto no caso das coñecidas "excepcións" reás e cadrís (Ilustracións 6 e 8) e algo menos alto no da tamén “excepción” papés (Ilustración 7); notable cos plurais de animal e fusil (Ilustracións 1 e 3); baixo cos de caravel e azul (Ilustracións 2 e 5); exiguo e en certos períodos nulo cos de español e tal (Ilustracións 4 e 9). Sobre os motivos polos cales o nivel de mantemento desta variante de plural é moi alto ou alto nos casos de reás, cadrís e papés e moi baixo ou nulo nos de españós e tas xa me pronunciei anteriormente, de modo que agora me limitarei a subliñar que os datos tomados das fontes escritas concordan cos extraídos das fontes metalingüísticas no tocante ás tendencias observables no desenvolvemento desta opción e á identificación dalgunhas das unidades lexicais que máis resistencia opuxeron ao seu abandono.

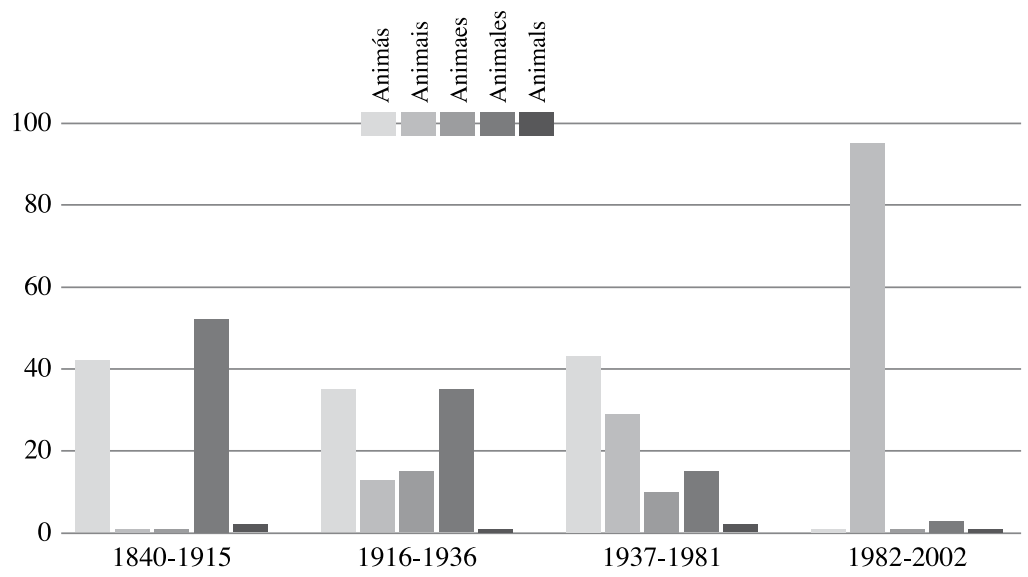

Ilustración 1. Plurais do substantivo animal no galego escrito entre 1840 e 2002.

Cómpre advertir que a leve recuperación de caravés entre 1937 e 1981 é máis aparente ca real, pois alicérzase sobre só dous rexistros desta variante (o 9,1\% dos casos) fronte a vinte (o 90,1\%) de caraveles. Ademais, o feito de que un deses dous rexistros de caravés se encontre nunha colectánea de cántigas populares de $1973^{27}$ move a sospeitar que esta forma de plural era xa naquela altura máis unha cousa do pasado (de onde proceden tanto os cantares transmitidos pola tradición oral coma as formas lingüísticas que estes conteñen) ca do presente.

27 Trátase do Cantigueiro popular da Limia Baixa (Vigo: Galaxia, 1973) recompilado por Xoaquín Lorenzo Fernández. 


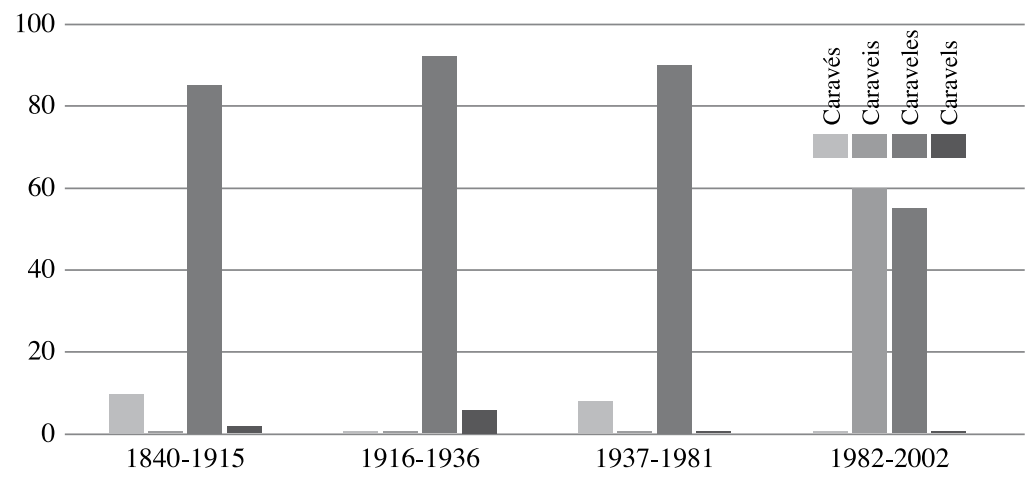

Ilustración 2. Plurais do substantivo caravel no galego escrito entre 1840 e 2002.

Moita máis importancia teñen, con certeza, os trinta e un usos de azús entre 1916 e 1936 (o 25,2\%) e os corenta e cinco da mesma variante deste adxectivo entre 1937 e 1981 (o 26,3\%), que marcan unha tendencia ben discordante respecto dos só cinco casos (o 5,3\%) de entre 1840 e 1915. Sen dúbida, azús foi un plural libre de sospeita castelanizante do que gustaron non poucos autores de textos publicados a partir da eclosión da etapa nacionalista, na que se sitúan as gramáticas de R. A. e Lugrís e mais a proposta normativa do Seminario de Estudos Galegos de 1933, que avogaron a favor da variante $-s$ con supresión de $-l$ para a formación destes plurais. Despois da Guerra Civil azús lese a partir de 1950 sobre todo en obras de autores máis ou menos próximos á Editorial Galaxia, que promoveu o uso desta variante do plural, canonizada pola gramática de Carballo Calero (publicada precisamente por Galaxia) ata 1974 e utilizada na redacción das normas ortográficas da RAG de 1970.

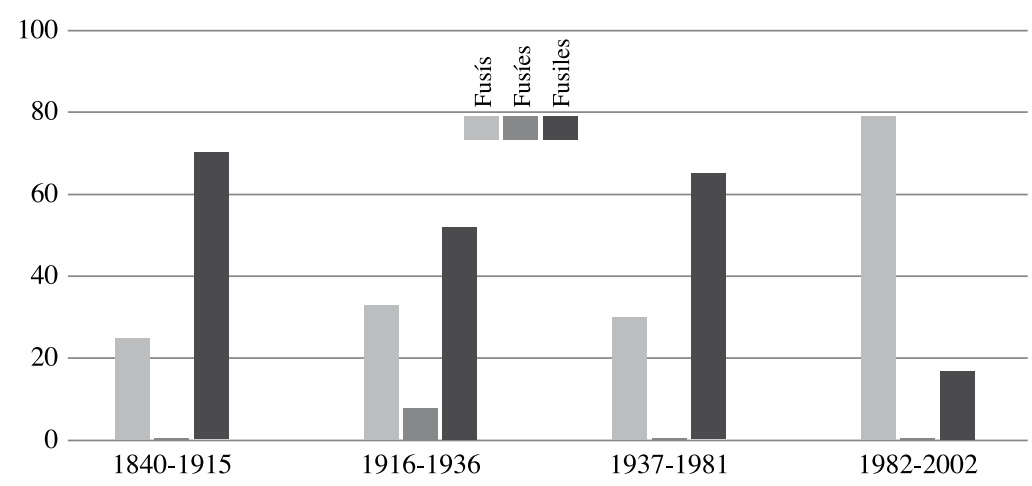

Ilustración 3. Plurais do substantivo fusil no galego escrito entre 1840 e 2002. 
$\mathrm{Na}$ realidade, o esforzo purista por recuperar ou manter esta variante entre $1916 \mathrm{e}$ 1981 apréciase tamén nos casos de animás e fusís, aos cales se lles poderían engadir outros como, por exemplo, currás, que atinxe unha representación do $30 \%$ entre 1916 e 1936 ( 3 rexistros de 10) e de nada menos ca o 58,8\% entre 1937 e 1981 (10 rexistros de 17).

Despois de 1982 o emprego desta variante só se mantivo con vigor cos nomes terminados en -il no singular (cos que é de regra no estándar) e mais coa reliquia reás, sobre a que as Normas da RAG e o ILG se pronunciaron dunha maneira que, a meu parecer, debeu de inducir a moitos a pensar que se trataba dunha excepción, se non promovida, si polo menos tolerada ou non mal vista no canto da normativa reais: "A solución animás -afirmaban a RAG e o ILG 1982: 52- debería ocupa-lo resto do territorio, pero só se oe en palabras illadas (como reás ou cadrís)". Con certeza, con esta excepción resultou decisivo o feito de que na gramática de Álvarez, Regueira e Monteagudo (1986: 67) se dixese taxativamente que "o plural de real é reás" e, xa máis tarde, que Freixeiro Mato (2000: 49) lle dispensase certa acollida na súa obra ao afirmar que "o substantivo real mantén a solución patrimonial centrooccidental reás no plural na fala e na lingua literaria, en convivencia coa oriental e común reais".

A sentenza normativa a prol da variante animais, caraveis, etc. significou o rápido eclipse de animás, caravés, etc. no galego escrito e/ou publicado despois de 1982.

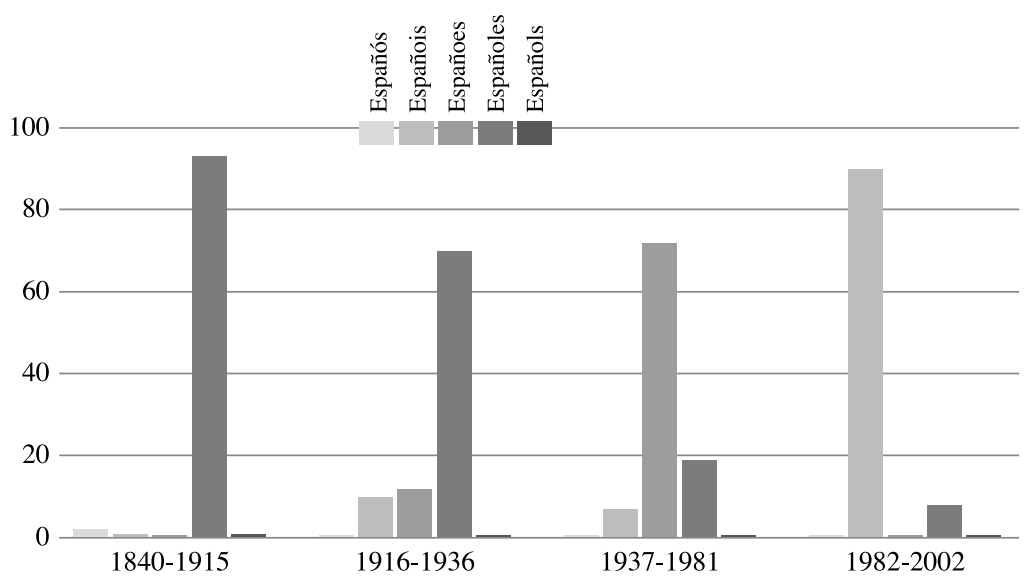

Ilustración 4. Plurais do substantivo e adxectivo español no galego escrito entre 1840 e 2002. 


\section{2. -is, con supresión do -l final do singular}

En xeral, esta variante utilizouse pouco entre 1916 e 1982 e moi pouco antes de 1916. Os seus contados rexistros de entre 1840 e 1915 adoitan estar condicionados pola orixe xeográfica oriental dos autores das obras en que se atopan: españois, reais e tais lense nos ensaios poéticos do berciano Fernández y Morales, do ano 1861, e papeis nunha entrega de 1913 da publicación fonsagradina O Tio Pepe. Chama a atención, con todo, o considerable nivel de uso de tais, plural de tal, mais é preciso recoñecer que lle debe moito á constancia con que en 1886, 1888 e 1889 foi empregado en dúas publicacións periódicas da cidade de Pontevedra: $O$ Galiciano (con 24 rexistros) e $O$ Novo Galiciano (con 9 rexistros).

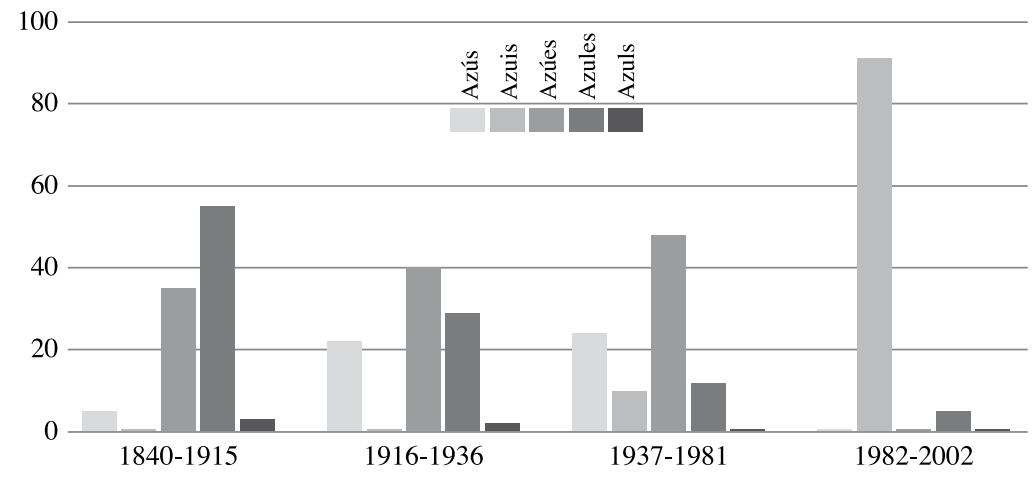

Ilustración 5. Plurais do adxectivo azul no galego escrito entre 1840 e 2002.

O ánimo purista que inspirou o cultivo do galego de non poucos autores despois de 1916 abonda para explicar o moderado progreso do uso escrito desta variante entre ese ano e 1981, progreso que se revela máis ostensible nos casos de animais, españois e papeis e algo menos nos de azuis e tais $^{28}$. Se antes da Guerra Civil foi o nacionalista Vicente Risco o escritor que máis salientou no seu gusto por ela, no período posterior o seu gran salto adiante non empezou a producirse ata despois de 1971, é dicir, ata despois de que a RAG, na súas Normas ortográficas e morfolóxicas do idioma galego dese ano, emitise unha prescrición favorable a ela.

28 O insignificante nivel de emprego atinxido por reais (na súa variante fonética rais) entre 1937 e 1981 concrétase en tres únicos rexistros que ademais se achan non en textos propiamente escritos, senón en transcricións de textos dialectais orientais publicados na década de 1970: un nas Narraciones orales gallego-asturianas (1972) de Dámaso Alonso e dúas na Etnografía del Valle de Ancares (1978) de José Ramón Fernández González. 
Despois de 1982 o esperable avance desta variante verificouse rapidamente, con algunha competencia dos plurais terminados en -les que máis adiante será comentada.

\section{3. -es, con supresión do -l final do singular}

É unha variante minoritaria que, con todo, antes de 1982 acadou unha discreta frecuencia de uso nos casos de animaes, azúes e taes e, con especial significación mais cun importante matiz que a seguir expoñerei, tamén no caso de españoes. Animaes, azúes e taes (e especialmente azúes e taes) foron formas que alcanzaron unha notable fortuna na literatura posterior á segunda metade do século XIX, pois circularon con profusión entre escritores de distintas tendencias ideolóxicas, diversas procedencias xeográficas e diferentes estilos. Poida que azúes se beneficiase do feito de ser empregada por Rosalía de Castro, o gran clásico da literatura galega moderna, na segunda edición dos seus Cantares Gallegos, aparecida en 1872. A variante españoes, que antes da Guerra Civil foi unha solución da que gustaron escritores nacionalistas como Vicente Risco, Antón Villar Ponte, Ramón Villar Ponte, Manuel Antonio ou Ramón Otero Pedrayo, aparece como forma maioritaria no período posterior (cunha cota do 74,4\%) só porque foi utilizada ata en 217 ocasións polo tamén nacionalista Alfonso Rodríguez Castelao no seu Sempre en Galiza (1944).

Despois de 1982 os niveis de emprego desta variante de plural son insignificantes.

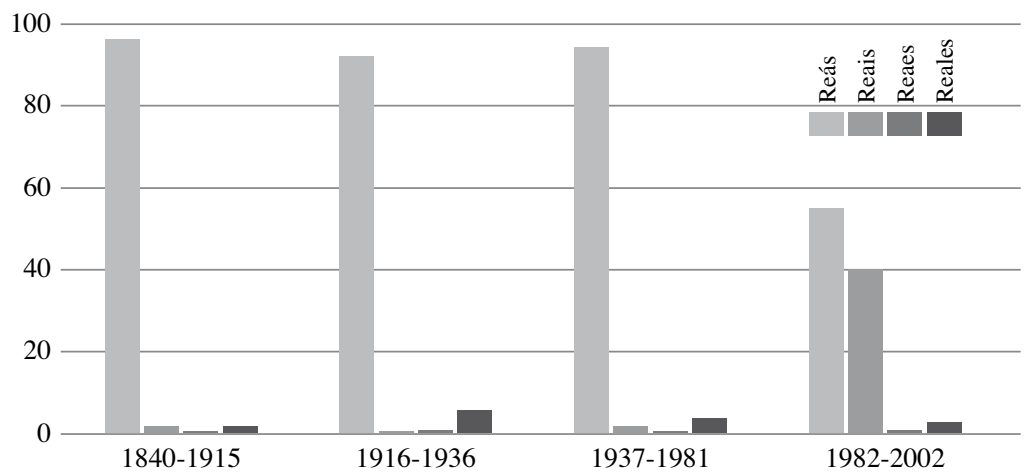

Ilustración 6. Plurais do substantivo real 'unidade monetaria' no galego escrito entre 1840 e 2002. 


\section{4. -es, sen supresión do -l final do singular}

Antes de 1982 gozou dun elevado nivel de uso, nomeadamente nos casos de caraveles, fusiles, españoles ${ }^{29}$ e tales. Aínda que tamén importante, foi sensiblemente menos frecuente a súa selección coas unidades animales, azules e papeles. Finalmente, as súas porcentaxes de uso resultan moi baixas ou mesmo insignificantes nos casos dos substantivos reales e cadriles. Podemos, por tanto, reiterar aquí a idea de que esta variante converxente co castelán xa gozaba dunha notable difusión na segunda metade do século XIX e repetir a observación de que, debido a causas diversas ás que xa se aludiu, ao seu avance posterior opuxeron máis resistencia unhas unidades lexicais ca outras. No moderno galego escrito transparentáronse estas diferenzas entre os ritmos de difusión desta innovación ás distintas palabras susceptibles de adoptala.

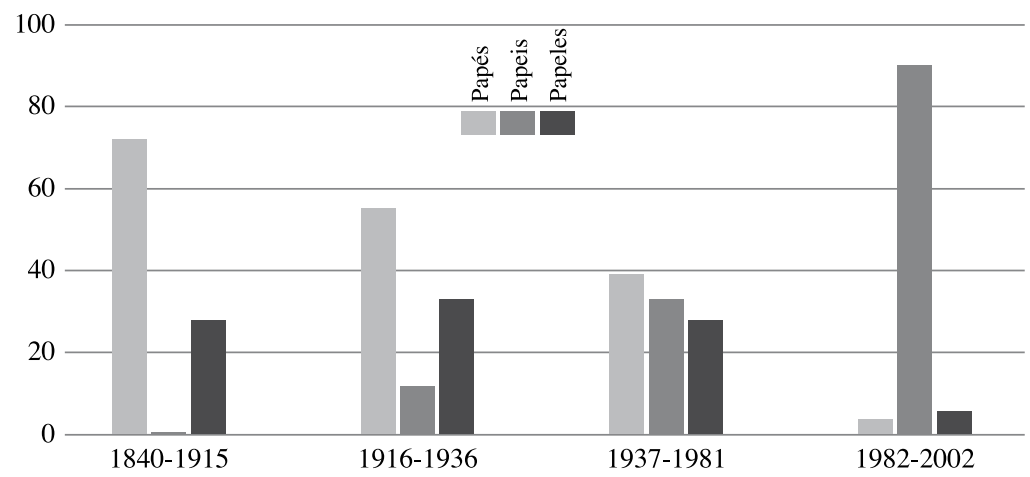

Ilustración 7. Plurais do substantivo papel no galego escrito entre 1840 e 2002.

Despois de 1982 o seu uso decaeu notoriamente agás coas palabras monosilábicas (tal-tales, etc.) e coas palabras compostas cuxo segundo lexema é un monosílabo

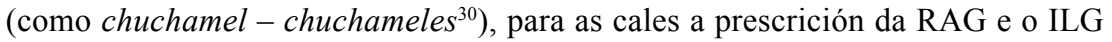

29 Intimamente vinculada coa ideoloxía segregada durante o proceso de construción do moderno estado español, a variante españoles utilizouse con contudente maioría entre 1840 e 1915 (no 94,3\% dos casos rexistrados) e algo menos entre 1916 e 1936 (co 70,8\%), cando comezou a ceder, sobre todo, ante dúas variantes promocionadas polos autores con actitudes máis puristas: españois (13\%) e españoes $(14,6 \%)$. No período posterior chegou incluso a facerse minoritaria (co 19,6\%) debido ao sistemático e frecuentísimo uso que de españoes fixo Castelao no Sempre en Galiza (1944).

30 Para o período abranguido entre 1840 e 2002 o TILG ofrece dous rexistros do plural chuchamelos, un de chuchamels e trinta e dous de chuchameles. Entre 1982 e 2002 a mesma fonte amosa, fronte a oito casos de chuchameles, soamente un de chuchamelos. 
correu ao seu favor. Coas outras voces aquí exploradas os rexistros desta variante pertencentes a esta época, minoritarios nuns casos (caraveles, fusiles) e sumamente escasos noutros (animales, españoles, azules, reales, papeles, cadriles), proceden a miúdo de fontes en que o que se recolle non é na realidade galego escrito, senón galego oral popular: cando non se trata de memorias de licenciatura ou de teses de doutoramento que conteñen transcricións de gravacións de actos de fala en que se utilizou un rexistro informal moi achegado aos caracteres propios do falar dunha determinada comarca, trátase do Cancioneiro popular galego (1984-1995) editado por Dorothé Schubarth e Antón Santamarina. Noutras ocasións estes plurais aparecen en obras destes anos escritas propositadamente na variedade do galego de Asturias, onde non se perdeu o /1/ intervocálico durante a etapa constitutiva do romance.

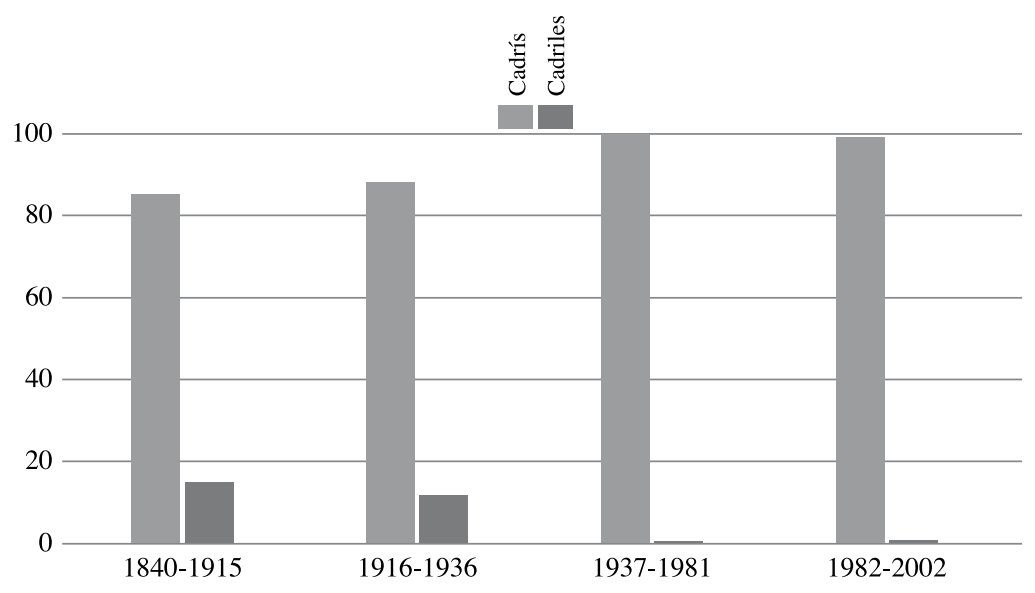

Ilustración 8. Plurais do substantivo cadril no galego escrito entre 1840 e 2002.

\section{5. -s, sen supresión do -l final do singular}

Na nosa moderna tradición escrita esta variante só atinxiu as residuais porcentaxes que cabía esperar da súa condición de solución moi minoritaria na lingua oral popular coetánea. As relativas excepcións que a esta pauta se lle poden sinalar distan de ter entidade suficiente para a invalidar: dous rexistros de vinte e dous (o 6,1\%) para caravels entre 1916 e 1936, catro de noventa e cinco (o 4,2\%) para azuls entre 1840 e 1915 e pouco máis. 


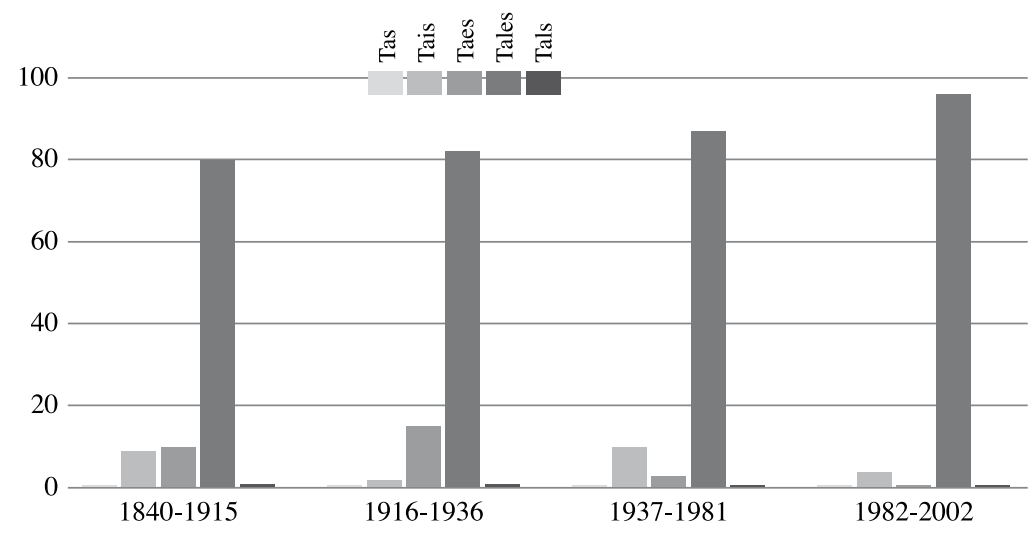

Ilustración 9. Plurais do identificador tal no galego escrito entre 1840 e 2002.

\section{Conclusións}

Polo que se refire á lingua da proximidade entre emisor e receptor, os datos tomados dos distintos tipos de fontes exploradas permítennos afirmar que a variante tradicional animás aínda debía de gozar dun notable nivel de uso na Galicia central e occidental a mediados do século XIX e que posteriormente, conforme foi aumentando o número de individuos con condutas bilingües galego-castelás ou polo menos con coñecemento pasivo do castelán, experimentou un rápido retroceso en beneficio de animales que a abocou á marxinalidade en que xa a presentan sumida os traballos de investigación realizados na segunda metade do XX. Como adoita suceder en toda mudanza lingüística, a innovación animales avanzou máis velozmente cunhas palabras ca con outras, e por distintas razóns algunhas unidades opuxéronlle particular resistencia (reás, cadrís, papés...). A variante animais conservouse ata hoxe como produtiva en moitos falares populares do centro e o sur do leste do territorio galegofalante; a meu ver, a súa selección como variante propia do estándar socializado a partir da década de 1980 está a propiciar a súa incorporación ao discurso oral informal de persoas que tiveron como primeira lingua adquirida o español mais que por distintos motivos utilizan con maior ou menor frecuencia o galego e tamén ao de individuos que, aínda que adquirisen na infancia algunha variedade popular do galego con plurais terminados en -les, van introducindo solucións propias do estándar nas súas interaccións lingüísticas cotiás; entre os aínda minoritarios grupos de persoas que tiveron como lingua inicial o galego estándar ou unha variedade próxima a el, animais é a solución empregada habitualmente tanto nos contextos 
formais coma nos informais. Pola súa parte, animaes e animals son variantes minoritarias que desde mediados do século XIX ata hoxe deberon de se manter con poucas alteracións nas contadas falas populares en que se utilizan, orientais no caso de animaes e occidentais no de animals. Cos monosílabos o uso oral popular foi durante todo este tempo, case sen excepcións, o da variante con desinencia -es e /1/ conservado.

No tocante á lingua da distancia, convén distinguir entre o uso escrito e o uso oral. As variantes do tipo de animás gozaron dun considerable nivel de uso na literatura decimonónica e, con desigualdades entre unhas palabras e outras, beneficiáronse do aprecio que non poucos escritores amosaron por elas entre 1916 e 1981. Foron ademais as que o Seminario de Estudos Galegos prescribiu en 1933 e aínda as que a Real Academia Galega utilizou na redacción do seu opúsculo ortográfico de 1970 e as que Carballo Calero apoiou ata a cuarta edición da súa gramática, de 1974. Non obstante, a decantación académica a prol da variante animais en 1971 acabaría por revelarse como unha reorientación destinada a perdurar, pois, logo de que os métodos de aprendizaxe do Instituto da Lingua Galega (favorables a animales) a contradixesen durante uns anos e despois de que as Bases de 1977 aínda lle recoñecesen animales como alternativa tolerable, foi consagrada polas Normas da RAG e o ILG de 1982. Evidentemente, o que prevaleceu á hora de optar por esta prescrición non foi o desexo de se achegar á variante maioritaria no galego popular contemporáneo, senón o espírito depurador, descastelanizador e harmonizador co portugués que en maior ou menor medida xa se viñera revelando na tradición escrita anterior. Con excepcións coma a de españoes no Sempre en Galiza (1944) de Castelao, as variantes do tipo de animaes e de animals foron pouco usadas no galego escrito moderno, especialmente as segundas; con todo, animaes beneficiouse da acollida favorable que lle dispensaron as gramáticas de Valladares e Carré Alvarellos. En xeral, cos monosílabos o uso escrito predominante foi o das variantes rematadas en -les.

Carecemos de fontes de estudo que nos permitan facer un seguimento da liña evolutiva da variable morfolóxica aquí estudada no galego utilizado oralmente en contextos formais desde mediados do século XIX ata hoxe. Así e todo, polas razóns que apuntei con anterioridade, paréceme sensato supoñer que esa liña evolutiva debeu de coñecer un trazado non moi distanciado do que acabo de sinalar para a lingua escrita. Antes de 1982, e quizais sobre todo entre os oradores máis comprometidos coa tarefa de descastelanizar o galego, debeu de predominar a preferencia polas variantes tradicionais sen mantemento de /1/ (animás, animais, animaes). Despois de 1982 os oradores máis esixentes e mellor preparados adoptan nos seus discursos a variante estándar animais, de modo que o uso de animales, sobre todo se é reiterado, se considera un sinal de descoido e de baixa competencia lingüística; as variantes 
animás, animaes e animals non se utilizan hoxe neste rexistro. Por outra banda, nos últimos tempos a variante animais comezou a competir con animales tamén na actividade lingüística de individuos con estudos e fasquía urbana que, situados en contextos de semiformalidade, intentan aproximarse no posible á variedade estándar. Cos monosílabos prevalece a adopción da solución terminada en -les, mais os oradores con convicións reintegracionistas adoitan usar con eles a variante -is (tais, cais ou quais, etc.).

A meu parecer, a exposición anterior invítanos a concluír este artigo cunha brevísima reflexión que, de podermos contar co espazo que aquí nos falta, deberiamos corroborar con suficientes exemplos tomados de mudanzas acontecidas en situacións de contacto lingüístico parangonables coa galega. Considero que no caso do galego contemporáneo as innovacións lingüísticas que supoñen unha converxencia co castelán ou un achegamento a el tiveron na lingua da proximidade un ritmo de difusión máis rápido do que tiveron na lingua da distancia (oral ou escrita). $\mathrm{Na}$ lingua da proximidade o aumento da presión exercida do século XIX para acó polo idioma dominante encontrou poucas resistencias ao seu avance, cousa que semella lóxica se pensamos na indefensión en que ata hai moi pouco se achou o galego, percibido por moitos dos seus falantes como un simple dialecto ou variedade baixa do castelán. Polo contrario, sobre a lingua da distancia actuou con rigor crecente unha reacción purista inserida no marco dun proceso de reemerxencia e elaboración lingüísticas contrario á dialectalización do galego baixo o dominio exercido sobre el polo castelán. Logo da elaboración da variedade estándar e do inicio da súa socialización a través de institucións e organizacións públicas e privadas, as formas propias da lingua da distancia parecen ir comezando a infiltrarse en certas variedades da lingua da proximidade.

Podemos aseverar tamén que, aínda que o purismo se revelou como un factor decisivo no proceso de estandarización (planificada) do galego moderno, a súa incidencia sobre a lingua escrita e sobre os crecentes espazos de uso oral que a esta lingua se lle foron abrindo no último século e medio da súa historia arrinca polo menos a mediados do século XIX, se ben se lle poden sinalar precursores coma o Padre Sarmiento (1695-1772). Concordo, por tanto, con Brincat / Boeder / Stolz (2003: viii) cando aseguran que non existe unha interdependencia entre a emerxencia de tendencias puristas nunha comunidade lingüística e a creación planificada dun estándar no seo dela, é dicir, que o purismo non nace sempre e necesariamente como un atributo dos procesos de elaboración consciente dun estándar, pois pódense mencionar casos de diversas linguas en que as actitudes puristas floreceron desconectadas de toda actividade conducente á forxa dun estándar. Segundo os autores antes mencionados, 'the English 'inkhorn term' debate of the $16^{\text {th }}$ century precedes the 'appeal to authority' in the $17^{\text {th }} / 18^{\text {th }}$ centuries" $\mathrm{e}$ "purism is an issue that 
can come up in societies where literacy is heavily restricted and institutions which could organise purist movements are largely missing" (Brincat / Boeder / Stolz 2003: viii). Creo, con todo, que, aínda que o purismo non estea necesariamente conectado cos procesos de elaboración consciente de variedades estándar, si é polo menos un comportamento que tende a asociarse co nacionalismo cultural e político en sentido amplo (cf. Thomas 1991); no caso galego pódese correlacionar o progresivo aumento da intensidade do purismo lingüístico desde mediados do século XIX ata hoxe co paralelo desenvolvemento cultural e político da consciencia da identidade galega durante toda esta época.

Finalmente, coido que, se é certo que o purismo exacerbado obstaculizou a revitalización de linguas ameazadas coma o tiwi australiano, o náhuatl ou o gaélico escocés (cf. Dorian 1994), no caso do galego moderno o que está a prevalecer é un purismo moderado que, sen abrir abismos entre a lingua da proximidade e a lingua da distancia, estase revelando como un factor capaz de expandir variantes diatopicamente pouco estendidas mais adornadas co gran atractivo de representaren unha tradición libre de toda sospeita de influencia castelanizante. Con certeza, a proximidade entre as estruturas fonolóxicas, morfolóxicas, sintácticas e lexicais do galego e o castelán esixe neste caso unha severa pero prudente actitude de vixilancia para impedir que o galego se desnaturalice por completo como consecuencia dun corremento cara ao castelán que acabaría por convertelo, tanto para os galegos coma para os non galegos, nunha simple variante deturpada e empobrecida do idioma español.

\section{Fontes exploradas}

\section{Gramáticas sincrónicas}

Álvarez, R. / Regueira, X. L. / Monteagudo, H. (1986): Gramática galega (Vigo: Galaxia).

Álvarez, R. / Xove, X. (2002): Gramática da lingua galega (Vigo: Galaxia).

Carballo Calero, R. (1966): Gramática elemental del gallego común. 266 pp. (Vigo: Galaxia) [2a ed., 1968, 286 pp.; $3^{\mathrm{a}}$ ed., 1970, 338 pp.; 4ª ed., 1974, 330 pp.; $7^{\mathrm{a}}$ ed., 1979, 346 pp].

Carré Alvarellos, L. (1967): Gramática gallega (A Coruña: Imprenta Moret).

Cornu, J. (1906): “Gramática de la Lengua Portuguesa. Apéndice: Morfología del gallego moderno", Boletín de la Real Academia Gallega 1, 7-9; 2, 28-30; 3, 52-54; 4, 75-77; 5, 99-101. 
Costa Casas, X. X. / González Refoxo, M. A. / Morán Fraga, C. C. / Rábade Castiñeira, X. C. (1988): Nova gramática para a aprendizaxe da língua (A Coruña: Vía Láctea).

Cuveiro, J. (1868): El habla gallega. Observaciones y datos sobre su origen y vicisitudes (Pontevedra: Imp. de José A. Antúnez y Ca).

Freixeiro Mato, X. R. (2000): Gramática da lingua galega. II. Morfosintaxe (Vigo: A Nosa Terra).

Lugrís Freire, M. (1931) [1ª ed.: 1922]: Gramática do idioma galego. $2^{\mathrm{a}}$ ed. (A Coruña: Imprenta Moret) [Edición facsímil: Santiago de Compostela: Consello da Cultura Galega, 2006].

Mirás, F. (1864): Compendio de gramática gallega-castellana (Santiago: Establecimiento tipográfico de Manuel Mirás) [Ed. facsímil: Madrid: Akal, 1978].

R. A. [atribuído a L. Carré Alvarellos] (1919): Compendio de gramática galega (A Coruña: Imprenta Nova).

Saco Arce, J. A. (1868): Gramática gallega (Lugo: Soto Freire) [2ª ed.: Ourense: Gráficas Tanco, 1967].

Santiago y Gómez, J. de (1918): Filología de la lengua gallega (Santiago de Compostela: Tip. de El Eco Franciscano).

Valladares, M. (1970) [ms.: 1892]: Elementos de gramática gallega (Vigo: Galaxia).

\section{Gramáticas diacrónicas}

Couceiro Freijomil, A. (s.d.): "El idioma gallego", en Carreras y Candi, F. (dir.), Geografía general del Reino de Galicia. Vol. 1, 161-327 (Barcelona: Casa Editorial Alberto Martín).

Couceiro Freijomil, A. (1935): El idioma gallego: historia, gramática, literatura (Barcelona: Alberto Martín).

García de Diego, V. (1909): Elementos de gramática histórica gallega (fonéticamorfología) (Burgos: Hijos de Santiago Rodríguez) [Ed. facsímil: Anexo 23 de Verba (Anuario Galego de Filoloxía). Universidade de Santiago de Compostela, 1984].

Ferreiro, M. (1995): Gramática histórica galega (Santiago de Compostela: Laiovento). 


\section{Propostas normativas}

Asociación Sócio-Pedagóxica Galega (1980): Orientacións para a escrita do noso idioma (A Coruña: Xistral).

Associaçom Galega da Língua (1983): Estudo crítico das Normas ortográficas e morfolóxicas do idioma galego ([A Coruña]: AGAL) [2a ed. corrigida e acrescentada: [A Coruña]: AGAL, 1989].

Bases prá unificación das normas lingüísticas do galego (= Bases). Madrid: Anaya, 1977.

Comisión de Lingüística - Xunta de Galicia (1980): Normas ortográficas do idioma galego (Santiago de Compostela: Xunta de Galicia). Utilicei a seguinte edición: Rábade, X. C. (1980): Normas ortográficas do idioma galego. Texto integro. Guía e comentario (A Coruña: La Voz de Galicia).

Instituto de la Lengua Gallega (1971): Gallego 1 (Universidade de Santiago de Compostela).

Instituto de la Lengua Gallega (1972): Gallego 2 (Universidade de Santiago de Compostela).

Real Academia Gallega (1970): Normas ortográficas do idioma galego (A Coruña: RAG).

Real Academia Gallega (1971): Normas ortográficas e morfolóxicas do idioma galego (A Coruña: RAG).

Real Academia Galega / Instituto da Lingua Galega (1982): Normas ortográficas e morfolóxicas do idioma galego (Vigo: RAG / ILG) [13 ${ }^{\mathrm{a}}$ ed. revisada, 1995; $18^{\mathrm{a}}$ ed. revisada: 2003].

Seminario de Estudos Galegos (1933): Algunhas normas pra a unificazón do idioma galego (Santiago de Compostela: Nós).

\section{Traballos de investigación}

ALGa 2: Instituto da Lingua Galega (1995): Atlas lingüístico galego. Vol. 2: Morfoloxía non verbal (A Coruña: Fundación Pedro Barrié de la Maza, Conde de Fenosa).

Dubert García, F. (1999): Aspectos do galego de Santiago de Compostela. Anexo 44 de Verba (Anuario Galego de Filoloxía) (Universidade de Santiago de Compostela). 
Dubert García, F. (2002): “Os sociolectos galegos”, Cadernos de Lingua 24, 5-27.

Fernández Rei, F. (1990): Dialectoloxía da lingua galega (Vigo: Edicións Xerais de Galicia).

Freixeiro Mato, X. R. / Sánchez Rei, X. M. / Sanmartín Rei, G. (2005): A lingua literaria galega no século XIX (A Coruña: Universidade da Coruña).

Mariño Paz, R. (2003): O idioma galego no limiar da súa renacenza. Estudo lingüístico de textos pregaleguistas. Monografía 2 da Revista Galega de Filoloxía (A Coruña: Universidade da Coruña).

Regueira, X. L. (1999): “Estándar oral e variación social da lingua galega”, en Álvarez, R. / Vilavedra, D. (eds.), Cinguidos por unha arela común. Homenaxe ó profesor Xesús Alonso Montero. I, 855-875 (Santiago de Compostela: Universidade de Santiago de Compostela).

Regueira, X. L. (2003): "Lingua falada e estándar escrito: O galego desde o Rexurdimento á modificación ortográfica de 2003”, Galicia dende Salamanca 4, 185-220.

Regueira, X. L. (2005): “Estándar oral”, in R. Álvarez \& H. Monteagudo (eds.): Norma lingüística e variación, 69-95 (Santiago de Compostela: Instituto da Lingua Galega / Consello da Cultura Galega).

Sánchez Rei, X. M. (2006): A lingua galega no cancioneiro de Pérez Ballesteros (Santiago de Compostela: Laiovento).

\section{Tesouros informatizados}

TILG: A. Santamarina (dir.) (2003): Tesouro Informatizado da Lingua Galega (Instituto da Lingua Galega / Universidade de Santiago de Compostela). Dispoñible en: http://www.ti.usc.es/TILG/.

\section{Bibliografía}

Brea, M. (1994): "Galegisch: Grammatikographie und Lexikographie / Gramaticografía y lexicografía”, en Holtus, G. / Metzeltin, M. / Schmitt, Ch. (eds.), Lexikon der Romanistischen Linguistik. Vol. 6, 2: Galegisch, Portugiesisch, 110-129 (Tübingen: Max Niemeyer).

Brincat, J. / Boeder, W. / Stolz, Th. (2003): "Preface", en Brincat, J. / Boeder, W. / Stolz, Th. (eds.) (2003), Purism in minor languages, endangered languages, 
regional languages, mixed languages. Papers from the conference on 'Purism in the Age of Globalisation' (Bremen, September 2001), vii-xiv (Bochum: Universitätsverlag Dr. N. Brockmeyer).

Dorian, N. C. (1994): "Purism vs. compromise in language revitalization and language revival", Language in Society 23, 4, 479-494.

Freixeiro Mato, X. R. (1998): Gramática da lingua galega. I. Fonética e fonoloxía (Vigo: A Nosa Terra).

García, C. (1971): “Orixen e problemas do método de galego”, Grial 32, 129-141.

Mariño Paz, R. (2004): “Diacronía da Formación do Plural dos Nomes Oxítonos Galegos Terminados en /1/ no Singular", en Brito, A. M. et alii (orgs.), Linguística Histórica e História da Língua Portuguesa. Actas do Encontro de Homenagem a Maria Helena Paiva (Faculdade de Letras da Universidade do Porto, 5-6 de novembro de 2003), 169-195 (Porto: Universidade do Porto).

McMahon, April M.S. (1994): Understanding Language Change (Cambridge: Cambridge University Press).

Sánchez Rei, X. M. (2005): “Trazos xerais da tradición gramatical galega”, Revista Galega de Filoloxía 6, 93-121.

Santamarina, A. (1974): “Gramática”, en Gran Enciclopedia Gallega. Vol. 16, 191195 (Xixón: Silverio Cañada).

Santamarina, A. (1994): "Norma e estándar", en Holtus, G. / Metzeltin, M. / Schmitt, Ch. (eds.): Lexikon der Romanistischen Linguistik. Vol. 6, 2: Galegisch, Portugiesisch, 66-79 (Tübingen: Max Niemeyer).

Thomas, G. (1991): Linguistic purism (London / New York: Longman). 